\title{
De las catacumbas a los últimos confines: violencia, sentido y representación en los periplos del martirio*
}

\author{
Carlos Arturo Salamanca Villamizar
}

\section{RESUMO}

Neste artigo proponho uma análise transversal das figuras do mártir e do martírio. Usando a noção de mediação, na primeira parte eu tento analisar o papel de liderança de representações de martírio em práticas de memória durante a segunda metade do século XVI. Eu analiso algumas das condiçóes que contribuíram para o surgimento de uma "cultura do martírio" e o papel da mediação nesta emergência. Na segunda parte, eu estudo como a (re) descoberta das catacumbas romanas abriu um campo de produção de significados em torno da figura do martírio. Na terceira parte, com foco na Companhia de Jesus, analiso algumas mediações pelas quais as representações do martírio transgrediram as fronteiras de igrejas e conventos para se projetar nas fronteiras de um mundo em plena expansão mundial.

Palavras-chave: mártir; mediações; jesuíta; catacumbas romanas; missionário.

\section{RESUMEN}

En este trabajo propongo un análisis transversal de las figuras del mártir y del martirio. Recurriendo a la noción de mediación, en la primera parte analizo el rol protagónico de las representaciones del martirio en las prácticas de la memoria durante la segunda mitad del siglo XVI. Analizo algunas de las condiciones que contribuyeron a la emergencia de una "cultura del martirio" y el rol de las mediaciones en tal surgimiento. En la segunda parte, estudio la forma en que el (re)descubrimiento de las catacumbas romanas, abrió un campo de producción de sentido en torno a la figura del martirio. En la tercera parte, centrándome en la Compañía de Jesús, analizo algunas mediaciones a través de las cuáles las figuras del martirio transgredieron las fronteras de iglesias y conventos para proyectarse a los últimos confines en un mundo en plena expansión.

Palabras clave: mártir; mediaciones; jesuita; siglo XVI; misionero.

DOI - http://dx.doi.org/10.1590/2237-101X016030010

* Versiones anteriores a este trabajo fueron presentadas en encuentros y seminarios en Bogotá (Centro Ático de PUJ, 2013), y Buenos Aires (Seminario General, IDAES, Universidad Nacional de San Martin, 2014). Agradezco a Germán Rey y a Guillermo Wilde por sus invitaciones, y a los participantes de dichas reuniones que con sus comentarios y preguntas me impulsaron a revisar parte de los argumentos. Agradezco a Simone diSanti y Stefano Costantini de Stephano Tours (www.stefanorometours.com) por haberme autorizado a utilizar sus fotografías (Figuras n. 5, 6,7,8) 


\section{ABSTRACT}

This paper proposes a cross-sectional analysis of martyr and martyrdom. Through the notion of mediation, in the first part I analyze the leading role of representations of martyrdom in memory practices during the second half of the sixteenth century. I analyze some of the conditions that contributed to the emergence of a "martyrdom's culture" and the role of mediation in such emergence. The second part studies how the (re)discovery of the Roman catacombs encouraged the production of meanings around the figure of martyrdom. In the third part, focusing on the Society of Jesus, I analyze a few instances of mediation through which the figures of martyrdom transgressed the boundaries of churches and convents to project themselves to the last frontiers of a world in full expansion.

Keywords: martyr; mediations; Jesuits; sixteenth century; missionary.

\section{Introducción}

En su desarrollo, la investigación antropológica e histórica produce terrenos privilegiados de análisis y observación que resultan del entrecruce de variables espacio-temporales, y en los que es posible analizar fenómenos y dinámicas específicos. La historia, dice Rancière, está hecha tanto de hechos como de lazos que los vinculan. ${ }^{1}$ Tomadas como Grandes Acontecimientos, cuestiones como las "Guerras de Religión”, o el "Descubrimiento de América" han ido constituyéndose como unidades analíticas a partir del encadenamiento de acontecimientos y dinámicas, que permiten ciertos grados de coherencia y unidad. El "pasado histórico", afirma White, "está hecho de acontecimientos discretos cuya facticidad ha sido establecida por deliberación y cuyas relaciones entre sí son más o menos contingentes”.2

Interesado en la violencia y sus representaciones, mi análisis se sitúa en la articulación contingente entre tres campos que, aunque cronológicamente coincidentes segunda mitad del siglo XVI — han estado tradicionalmente escindidos: las guerras de religión, las políticas del martirio y las prácticas misionales. ¿Qué vínculos pueden establecerse entre las narrativas acerca de la muerte de los hugonotes de la San Bartolomé y de los misioneros muertos a manos de los infieles americanos?, ¿entre las prácticas discursivas en torno a las catacumbas romanas y a aquellos confines remotos en que la sangre de jesuitas se convirtió en semilla de cristianos?, ¿entre las representaciones de la

\footnotetext{
${ }^{1}$ RANCIÈRE, Jacques. Figuras de la Historia. Buenos Aires: Eterna cadencia, 2013 [2012].

${ }^{2}$ WHITE, Hayden. El pasado práctico. In: TOZZI, Verónica y LAVAGNINO, Nicolás. Hayden White, la escritura del pasado y el futuro de la historiografía. Buenos Aires: Eduntref, 2012. p. 19-40.
} 
herejía y las de la infidelidad?

Este trabajo se sitúa en la línea de autores como Gruzinski quien, emprendiendo una lectura simultáneamente situada en los reinos europeos conquistados por la Reforma y la América española - México en particular - identificó, entre otros, un proceso simultáneo y paralelo de iconoclastia: "en la Inglaterra de los Tudor se cubren las iglesias con cal", afirma el autor, de la misma forma que "en México se habían blanqueado ya las pirámides". 3 Análisis transversales como éstos permiten ver la forma en que fueron resueltas contradicciones como la hostilidad hacia los ídolos y la predicación con imágenes, o la naturaleza de la separación efectuada entre la imagen misma como objeto de idolatría y la imagen como objeto de remembranza, recuerdo, y memoria. ${ }^{4}$ Reconociendo que las representaciones son significativas de formas específicas y en contextos determinados, el análisis transversal y multi-situado permite preguntarnos por los mecanismos de adaptación, negociación e interpretación a través de los cuales dichas representaciones son producidas una y otra vez. ${ }^{5}$

Recurriendo a la noción de mediación, en la primera parte analizo el protagonismo de las representaciones del martirio en las prácticas de la memoria durante la segunda mitad del siglo XVI. Analizo algunas de las condiciones que contribuyeron a la emergencia de una "cultura del martirio" y el rol de las mediaciones en tal surgimiento. En la segunda parte, me refiero a la forma en que el (re)descubrimiento de las catacumbas romanas, abrió un campo de producción de sentido en torno a la figura del martirio. Un descubrimiento del pasado que implicaba también su producción en los espacios de lo cotidiano del espacio misional, en las rutinas y en el lenguaje habitual de iglesias y conventos. En la tercera parte, centrándome en la Compañía de Jesús, analizaré algunas mediaciones a través de las cuáles las figuras del martirio transgredieron las fronteras de iglesias y conventos de la ciudad para proyectarse hasta los últimos confines en un mundo en plena expansión, no sin dejar de reconocer que entre aquellas regiones y las iglesias y conventos, los viajes se producía en varios sentidos.

Aunque centrado en las figuras del martirio, este artículo se inserta en un proyecto más amplio sobre violencias y prácticas discursivas. La figura del mártir, lejos de quedar restringida geográficamente al contexto europeo, transciende sus fronteras de la mano de las prácticas de misión de distintas congregaciones.

Así como había sucedido con las prácticas y los tropos de las representaciones geográficas y antropológicas de la alteridad de siglos precedentes, ${ }^{6}$ las experiencias de encuentro con el nativo americano y con el otro en general, ${ }^{7}$ son interpretadas permanentemente a través de

${ }^{3}$ GRUZISNKI, Serge. La guerra de las imágenes. De Cristóbal Colón a "Blade Runner" (1492-2019). México: FCE, 1994 [1990]. p. 72.

${ }^{4}$ Ibid., p. 73.

${ }^{5}$ Cf. FREEDBERG, David. The hidden god: image and interdiction in the Netherlands in the sixteenth century. Art history, v. 5, n. 2, p. 133-153, 1982. p. 144.

${ }^{6}$ Cf. SALAMANCA VILLAMIZAR, Carlos A.. Saberes geográficos, tensiones de alteridad y teatros del martirio en las cartografías jesuíticas del nuevo mundo. (en prensa, Revista Española de Antropología Americana). ${ }^{7}$ Cf. VILLAMIZAR, Carlos A. S. Herejes e infieles: imaginación etnográfica, experiencia histórica y prácti- 
marcos específicos de significación. En las representaciones que aluden a la figura del martirio en América se sintetizan algunas de tensiones políticas en las que la religión tiene un rol estructurante. A su vez, la experiencia americana incidiría en las representaciones en torno a las tensiones religiosas, en un movimiento dialéctico entre los discursos de la experiencia histórica y la experiencia histórica de los discursos.

\section{Mediaciones de memoria y las narrativas del martirio}

Durante la segunda mitad del siglo XVI europeo se llevó a cabo una notable producción de pinturas murales, mapas, breviarios, panfletos, martirologios y grabados fundamentales en las prácticas de la memoria de la época. Tal producción tendría por epicentro ciudades como Amberes, Roma y París, y estaría atravesada por circuitos de circulación a múltiples escalas entre archivos, talleres de grabadores, muros de iglesias e imprentas. Imágenes de diferente formato, tamaño, calidad y naturaleza circularían a través de misarios, biblias, cartas de oración, estandartes y libros.

En esta explosión iconográfica intervino un número creciente de dibujantes, grabadores, editores e impresores, respaldado por un también creciente número de Iglesias, monarquías y empresarios interesados en el emergente mercado editorial. Aunque no será objeto de este trabajo, no menos importante son las personas y colectivos a quienes, bajo la forma de testigos o audiencias, parecía dirigirse dicha producción con diversos propósitos e intereses.

A partir de mi investigación sobre prácticas comunicativas en contextos de violencia masiva, he reconocido la noción de mediación como propia de las prácticas de la memoria y del recuerdo. Bajo esta categoría incluyo aquello que otros autores han definido como "lugares", "vehículos", "artefactos", 10 "tecnologías"11 o "mecanismos". ${ }^{12}$ Considero que estas denominaciones son insuficientes, entre otras razones, por focalizar la observación en una de las partes, por poner el acento en el medio o en su naturaleza, por no dar cuenta de las relaciones y de los vínculos que se establecen entre los agentes intervinientes, y por ignorar que la producción tiene un destinatario con el cual se busca, pretende o supone una relación o un vínculo especifico.

Tomando distancia de la lingüística estructural que aislaba el lenguaje de la realidad, del sujeto y de su dimensión intersubjetiva, Ricoeur afirmó que más que un objeto, el lenguaje

cas comunicativas de la alteridad en la obra de De Bry. Revista Brasileira de História das Religióes, v. 7, n. 19, p. 91-106, 2014.

${ }^{8}$ NORA, Pierre. Les lieux de mémoire. Gallimard: París, 1984.

${ }^{9}$ RICCEUR, Paul. La Mémoire, l'Histoire, l'Oubli. París: Seuil, 2003. p. 47.

${ }^{10}$ LIFSCHITZ, Javier Alejandro; ARENAS GRISALES Sandra Patricia. Memoria política y artefactos culturales. Estudios Políticos, n. 40, p. 98-119, 2012.

${ }^{11}$ TILL, Karen. Artistic and activist memory-work: Approaching place-based practice. Memory Studies, v. 1, n. 1, p. 99-113, 2008.

${ }^{12}$ ANDERSON, Benedict. Comunidades imaginadas. México: FCE, 2000. 
es una mediación y que dicha mediación se da, al menos en tres instancias: del sujeto con la realidad, entre el sujeto y otro, y del sujeto consigo mismo. ${ }^{13} \mathrm{La}$ idea de mediaciones permite incorporar al análisis las relaciones intersubjetivas de producción, circulación, negociación, y legitimación de discursos y representaciones, en situaciones y contextos específicos. La noción de mediación de memoria permite reconocer e integrar las diferentes instancias en las que personas y grupos establecen vínculos y relaciones en torno a prácticas como el recuerdo, la evocación y la conmemoración desde una perspectiva social. A su vez, permite incorporar tanto a los sujetos como a colectivos que, situados en los espacios intermedios y en las zonas de negociación, impulsan, diseñan, participan, y llevan a cabo estas prácticas. La amplitud de la categoría reside en la necesidad de señalar un conjunto de espacios/tiempo móviles en un campo constituido por un conjunto de nodos entre los cuales se establecen vínculos relacionales. La idea de mediación permite lecturas transversales de diferentes esferas tradicionalmente escindidas (lo artístico, lo político y lo social y lo religioso), y su vinculación con las demás esferas de la vida social, útiles para entender las formas en que se construye sentido y memoria. La noción de 'mediaciones' también abreva en las investigaciones sobre las performances del poder, ${ }^{14} \mathrm{y}$ la teatralización de la política, que evidencian que el poder nunca es sólo una cuestión de fuerza, sino también de lenguajes y discursos. ${ }^{15}$

Las pinturas murales, los mapas, los breviarios, los martirologios y los grabados pueden ser analizados en tanto mediaciones porque en su producción, circulación y uso median narrativas, significados que crean relaciones sociales. Siguiendo a Freedberg veremos cómo los frescos, los grabados y las mediaciones de memoria que analizaremos no son resultado exclusivo de un acto individual sino más bien hacen parte de una cultura visual siendo fundamental analizar los contextos en los que emergen y en los que se insertan. ${ }^{16}$

$\mathrm{Ni}$ verdaderas, ni transparentes ni puras, las mediaciones de memoria permiten observar tanto las características o la naturaleza de aquello que actúa como elemento mediador como las relaciones que se establecen entre los participantes. Aunque las mediaciones pueden ser reconocidas, descritas e identificadas en su especificidad, es preciso recordar que su naturaleza, sus características y sus tramas de significación dependen de diversas articulaciones coyunturales, dinámicas y cambiantes; así, las mediaciones son simultáneamente "objeto" y "proceso". Retomo aquí los estudios de las imágenes en relación con los contextos sociales

\footnotetext{
${ }^{13}$ RICCEUR, Paul. La Mémoire, l'Histoire, l'Oubli, op. cit, p. 47.

${ }^{14}$ BALANDIER, Georges. Le pouvoir sur scène. París: Fayard, 2006 [1980].

${ }^{15}$ GEERTZ, Clifford. Negara. The Theater State in Nineteenth Century in Bali. Princeton: Princeton University Press, 1980.

${ }^{16}$ FREEDBERG, David. The hidden god: image and interdiction in the Netherlands in the sixteenth century, op. cit., p. 133-153.
} 
en los que emergen, ${ }^{17}$ su agencia, ${ }^{18}$ su ontología y algunas dimensiones de su poder, ${ }^{19}$ sus procesos interculturales y "mestizos" de constitución, ${ }^{20}$ sus apariciones e interpretaciones en contextos sociales particulares ${ }^{21}$ o sus continuidades en múltiples contextos históricos. ${ }^{22}$ Aunque en diálogo con las teorías de la comunicación y de las relaciones de poder en torno a la producción y la recepción de las imágenes, intento llevar aun más lejos el análisis para incluir las mediaciones en sus instancias de producción, circulación y consumo.

\section{El martirio: el surgimiento de un "nuevo" género}

La producción, uso y circulación de gramáticas, mapas, biblias y otras obras de carácter religioso adquirió un gran impulso con la instalación de las primeras imprentas en Europa a finales del siglo XV, y ya para mediados del siglo XVI, la producción editorial se desarrollaba a una escala mucho mayor. Durante la primera mitad del siglo XVI las imágenes religiosas irían adquiriendo un sentido político como consecuencia de la Reforma y la Contrarreforma. El proceso doble y articulado de creciente politización de la religión y sacralización de la política a través de las imágenes tocaría su punto más alto durante la segunda mitad del siglo XVI con las confrontaciones entre católicos y protestantes, durante las llamadas Guerras de Religión (1562-1598). ${ }^{23}$

En dicho contexto, adquirió un lugar preponderante el martirio en tanto práctica en la que los mártires son reivindicados como actores e instrumentos de la imitación de Cristo. La emergencia de los martirologios se produjo de manera articulada a una serie de profundas transformaciones en las artes de la memoria y su relación con la violencia y su representación. Entre sus antecedentes se encuentran imágenes y pinturas referidas a temas provenientes de leyendas medievales como la joven Úrsula martirizada por los hunos y a acontecimientos de tenor hagiográfico como la masacre de los Santos Inocentes (Figura n. 1).

${ }^{17}$ FREEDBERG, David. The hidden god: image and interdiction in the Netherlands in the sixteenth century, op. cit., p. 133-153; BEZERRA DE MENESES, Ulpiano. Fontes visuais, cultura visual, História visual. Balanço provisório, propostas cautelares. Revista Brasileira de História, v. 23, n. 45, p. 11-36. 2003; CHALFEN, Richard. Photography. In: LEVINSON, David; EMBER, Melvin (Eds.). Encyclopedia of Cultural Anthropology. Nova York: Holt, 1996, n. 3, p. 926-31.

${ }^{18}$ GELL, Alfred. Art and agency. An Anthropological Theory. Oxford: Clarendon Press, 1998.

${ }^{19}$ FREEDBERG, David. The power of images. Studies in the History and Theory of Response. Chicago: University of Chicago Press, 1989.

${ }^{20}$ GRUZINSKI Serge. La Pensée métisse. París: Éditions Fayard, 1999.

${ }^{21}$ CHRISTIAN, William. Apariciones en Castilla y Cataluña (siglos XIV-XVI). Madri: Editorial Nerea, 1990; CHRISTIAN, William. Local Religion in Sixteenth-Century Spain. Princeton: Princeton University Press, 1989.

${ }^{22}$ BELTING, Hans. The End of the History of Art?. Chicago: The University of Chicago Press, 1987.

${ }^{23}$ BERCHTOLD, Jacques; FRAGONARD, Marie-Madeleine (Ed.) La mémoire des guerres de Religion. La concurrence des genres historiques, XVIe-XVIIIe siècles. Actes du colloque international de Paris. (15-16 novembre 2002) Genève: Droz, 2007. JOUANNA, Arlette et al. Historie et dictionnaire des guerres de religion. París: Laffont, 1998. 


\section{Figura n. 1}

Matanza de los Inocentes, SF.

Este grabado ha sido atribuido a Marco Dente (1490-1527) quien lo habría elaborado a partir de una obra de Baccio Bandinelli (1493-1560).

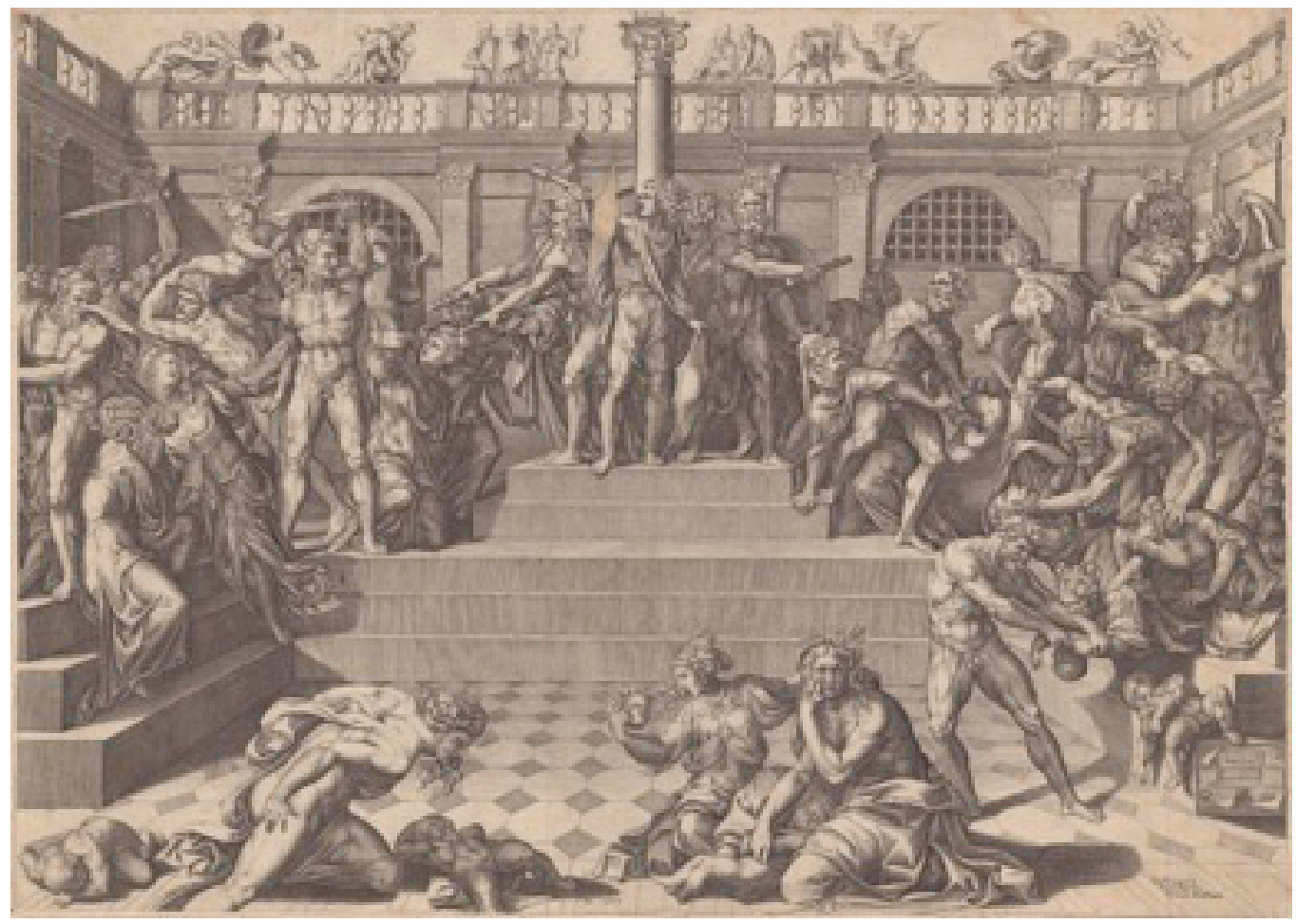

Fuente: The Metropolitan Museum of Art.

Número de acceso: 49.97.618, The Elisha Whittelsey Fund, 1949. (http://www.metmuseum.org)

Autores como Lestringant y Moireau han reconocido al martirologio como una puesta en escena polisémica que combina el rito judicial, el espectáculo público y el acto religioso; un dispositivo teatral que toma sus referentes del rito judicial del interrogatorio y del rito espectacular de los juegos de circo de la Roma imperial. ${ }^{24}$ En este acto comunicativo el mártir 'habla' a Dios, al público, a sus victimarios, a sus pares (a otros que murieron como él, a otros que morirán como él) a quienes se une por el mismo acto, constituyendo una comunidad en torno al acontecimiento.

Las prácticas comunicativas en torno al martirio retoman varias características de las prácticas de la memoria de las épocas clásica y medieval. Entre ellas, el arte de la memoria como un conjunto de repertorios de técnicas y ejercicios de ampliación y profundización de la memoria, los mapas y representaciones cartográficas como lugar de inscripción del cono-

\footnotetext{
${ }^{24}$ LESTRINGANT, Frank; MOREAU, Pierre-François. Ouverture. Revue de Sciences Humaines, n. 269, p. 7-13, 2003.
} 
cimiento sobre el mundo y síntesis de dicho conocimiento, y la noción de teatro, en tanto dispositivo de visualización, de puesta en escena y de noción de un orden y un repertorio de relaciones existente. ${ }^{25}$

A estas características se suman otras como la circulación de narrativas e imágenes que van y vienen entre los muros y las fachadas de conventos e iglesias, los grabados de los martirologios, y un sinnúmero de publicaciones religiosas como misarios, las semblanzas, cartas de oración que, entre otros, circulaban a través de los mismos peregrinos (Freedberg 1983, p. 41). Asimismo, es pertinente citar la forma en que las escenas del martirio ganan una visibilidad pública inédita contribuyendo eficazmente a la creación de nuevas audiencias. Por último, la coexistencia de narrativas en tensión e incluso opuestas y en conflicto con propósitos didácticos y ejemplarizantes como consecuencia de la Reforma protestante.

Aunque se manifiesta en diferentes partes de Europa, la "explosión" en las representaciones del martirio tiene como epicentro los reinos de Inglaterra y Francia, y algunas obras icónicas. Del lado protestante sobresalen el Libro de los Mártires, ${ }^{26}$ y los 40 Cuadros, ${ }^{27}$ mientras que del lado católico, vale la pena subrayarse Le Thêatre des Cruantés. ${ }^{28}$ Estos martirologios fueron precedidos por obras como las Actes de Martyrs. ${ }^{29}$

Aspectos particulares como las figuras retóricas de las representaciones del martirio utilizadas por católicos y protestantes en el contexto de las guerras de religión ya han sido analizados en otra parte; a efectos de introducir el análisis que realizaremos me limitaré a subrayar algunos elementos. Estas mediaciones, al mismo tiempo que registran, narran y re-presentan la crueldad y el heroísmo, establece unos "otros" y un "nosotros" entre los que se establece una guerra de imágenes por la legitimidad religiosa. Segundo, una pieza clave del dispositivo representacional del martirio tiene que ver con la forma en que son interpeladas las audiencias. En algunos casos apelando a la pasión colectiva y a la identificación entre el mártir y el lector-espectador e insertando las imágenes en estrategias en las que se interpelan las pasiones populares. En otros, sugiriendo un distanciamiento como condición para el acercamiento a la verdad histórica. Tercero, atravesado por la representación, el martirio no es una práctica discursiva, el mártir no es el único que habla ni el habla es la práctica preponderante en esta performance del espectáculo, pues existen múltiples tensiones entre

\footnotetext{
${ }^{25}$ SALAMANCA VILLAMIZAR, Carlos S. "Religión, política y espectáculo: narrativas del martirio en la primera modernidad", 2015, mimeo.

${ }^{26}$ FOXE, John. The Unabridged Acts and Monuments Online. 1576 [1563]. Sheffield: HRI Online Publications, 2011. URL: $<$ http//www.johnfoxe.org>. Consultado: 9-12-2013.

${ }^{27}$ PERRISSIN, Jean; TORTOREL, Jacques. Premier volume contenant quarante tableaux ou Histoires diverses qui sont mémorables touchant les Guerres Massacres et Troubles advenus en France en ces dernières années. Le tout recueilli selon les témoignages de ceux qui y ont été en personne, et qui les ont veus, lesquels sont pourtrais à la vérité. $\mathrm{S} / \mathrm{E}, \mathrm{S} / \mathrm{F}$.

${ }^{28}$ VERSTEGAN, Richard. Théâtre des cruautés des hérétiques de notre temps. Paris: Editions Chandeigne, 1995 [1557]. URL: <http://gallica.bnf.fr/ark:/12148/bpt6k1040506g>. Consultado: 12-3-2014.

${ }^{29}$ CRESPIN, Jean. Actes de Martyrs, S/E, 1554.
} 
quienes observan y son observados y a su vez entre quienes producen, observan e interpretan las pinturas, los grabados y las imágenes.

\section{Jubileo, inframundo y la figura del martirio}

\section{(re)descubriendo el martirio}

Durante la segunda mitad del siglo XVI, uno de los terrenos en los que se disputaba la legitimidad entre católicos y protestantes era la nitidez del vínculo que unía a unos y otros con la iglesia originaria. En Roma éste interés se dirigió a los primeros mártires, a sus reliquias y a sus restos. En ese marco, las catacumbas se constituyeron como uno de los lugares más significativos, bajo la idea de haber sido escenario de refugio de los primeros cristianos frente a las persecuciones de ocho emperadores consecutivos desde Nerón hasta Juliano. ${ }^{30}$ Comprometido con el cumplimiento de las conclusiones del Concilio de Trento, Gregorio XIII (1572-1585) emprendió una renovación moral de la iglesia de la que es pertinente subrayar dos elementos. Por una parte, la institucionalización y formalización de la preparación de sacerdotes y misioneros, concretizada en la creación de colegios y seminarios y en su racionalización y centralización en seminarios. ${ }^{31}$ Por otra, el despliegue y uso de la cultura del martirio ${ }^{32}$ materializándose en un interés por los lugares de los mártires que generaría un número creciente de excavaciones en busca de las catacumbas. ${ }^{33}$ Aunque la Roma subterránea operó como un verdadero epicentro, en varias ciudades europeas el martirio hacía parte de un verdadero air du temps. En Amberes por ejemplo, los mismos altares que hacían referencia al martirio y que décadas atrás habían enfrentado una severa ola de iconoclastia, empezaron a ser restaurados a partir de la década de $1560 .{ }^{34}$

La empresa arqueológica se propuso demostrar la antigüedad del Cristianismo y tuvo como protagonistas a Antonio Bosio (1575-1629), "padre de la arqueología cristiana" y al florentino Felipe Neri (1515-1595), "apóstol del Roma”, quienes no sólo impulsaron el culto

\footnotetext{
${ }^{30}$ No obstante, señala Osborne, las catacumbas fueron mucho más que un refugio y, al menos hasta el siglo VIII, un espacio social integrado a diferentes prácticas religiosas; de hecho, afirma el autor, el proceso de decline de las catacumbas no empezó sino en el siglo VIII. Cf. OSBORNE, John. The Roman Catacombs in the Middle Ages. Papers of the British School at Rome, n. 53, p. 278-328, 1985.

${ }^{31}$ RICHARDSON, Carol. Durante Alberti, the Martyrs' Picture and the Venerable English College, Rome, Papers of the British School at Rome, n. 73, p. 223-263, 2005. p. 223.

${ }^{32}$ OSSWALD, Cristina. A iconografia do martírio na Companhia de Jesus entre os sécs. XVI e XVIII. Revista Portuguesa de Filosofia, n. 65, p. 1301-1313, 2009. p. 1302.

${ }^{33}$ Acerca del lugar de las imágenes en el culto a los santos, las reliquias, como resultado de los decretos del Concilio de Trento. Cf. FABRE, Pierre Antoine. Décréter l'image? La XXV Veme session du Concile de Trente dans le texte. París: Les Belles Lettres, 2013.

${ }^{34}$ Cf. FREEDBERG, David. The Representation of Martyrdoms during the Early Counter-Reformation in Antwerp. Burlington Magazine, v. 876, n. 118, p. 128-138, 1976.
} 
a los mártires y las reliquias ${ }^{35}$ sino que trabajaron en la documentación de los murales y de las catacumbas. ${ }^{36}$ El hallazgo de la primera catacumba el 31 de mayo de 1578 constituiría la oportunidad de reconstituir el vínculo con la iglesia originaria, exaltar la veracidad de la doctrina derivada de su continuidad histórica y así, oponerla a las posiciones protestantes. En este marco, las sepulturas fueron declaradas "verdaderas", las catacumbas, "evidencia de la vigorosa persistencia de la iglesia", y el pasado cristiano "poderoso portador de salvación". ${ }^{37}$ El hallazgo/producción de esta geografía sagrada convertiría a la ciudad en lugar de encuentro con los más altos misterios de la fe, reforzando su condición de lugar de peregrinación; en estos ańos en los que además se difunden las traducciones de la 'Historia de Roma' de Apiano y sus historias de las persecuciones, ${ }^{38}$ los antiguos mártires nuevamente ungidos, se convertían en respuesta adecuada a las teorías protestantes.

El cardenal Cesare Baronio (1538-1607) fue una figura central en la promoción de una serie de políticas culturales cuyo eje principal era el martirio. ${ }^{39}$ Entre 1588 y 1607, Baronio elaboró una obra monumental de la historia de la iglesia cristiana en 12 tomos - los Anales Eclesiáticos - en respuesta a Las Centurias de Magdeburgo (1559-74) que declaraban la Iglesia Católica como contraria a la verdadera doctrina. Al cardenal también le fue confiada la revisión del Martirologio Romano por Gregorio XIII; Baronio publicó una primera versión en 1586 y una segunda, corregida, en 1589. Asimismo, impulsó la restauración de varias iglesias y la preservación de los monumentos de la antigua Roma como evidencia de los milagros, martirios y otros eventos memorables del Cristianismo. Bajo su égida se restauraron, entre otros, la iglesia de los Santos Nereo y Aquileo, cuyas actas de martirio, de acuerdo a Rodríguez de Cevallos, ${ }^{40}$ habían sido exhumadas y publicadas por el mismo Baronio. Sus iniciativas fueron reafirmadas por algunos de los Papas que siguieron a Gregorio XIII, espe-

${ }^{35}$ MONTORO CASTILLO, Mónica. 2008. Los oratorianos de San Felipe Neri y los inicios de la arqueología cristiana. CuPAUAM, n. 34, p. 147-154.

${ }^{36}$ OSBORNE, John. The Roman Catacombs in the Middle Ages, op. cit., p. 312. Aunque brevemente, subrayemos que esto constituye el indicio de una tendencia — creciente durante el siglo XVII en particular entre los jesuitas, de un movimiento articulado entre la interpretación simbólica y la investigación empírica. Como afirma Dekoninck, el emblemista va a tomar prestadas deducciones y observaciones de la historia natural, mientras que el científico, después de sus escrupulosas deducciones, estaría presto a proponer interpretaciones que habilitaran enseñanzas morales o religiosas. Uno y otro son dos dimensiones de un mismo proceso. Para un ejemplo ilustrativo de lo anterior, ver Figura no. 9. Cf. DEKONINCK, Ralph. Imaginar la ciencia: la cultura emblemática jesuita entre ars rethorica y scientia imaginum. In: CHINCHILLA, Perla; ROMANO, Antonella (Coord.). Escrituras de la modernidad. Los jesuitas entre cultura retórica y cultura científica. Ciudad de México: Universidad Iberoamericana, 2008, p. 143-160. p. 145.

${ }^{37}$ LABROT, Gérard. L'image de Rome: une arme pour la Contre-Réforme, 1534-1677. París: Champ Vallon, 1987. p. 77-80.

${ }^{38}$ EHRMANN, Jean. Massacre and Persecution Pictures in Sixteenth Century France. Journal of the Warburg and Courtauld Institutes, n. 8, p. 195-199, 1945.

${ }^{39}$ RODRÍGUEZ G. DE CEBALLOS, Alfonso. El mártir, héroe cristiano. Los nuevos mártires y la representación del martirio en Roma y en España en los siglos XVI y XVII. Quintana: Revista de estudios do Departamento de Historia da Arte, n. 1, p. 84-99, 2002. p. 91.

${ }^{40}$ Ibid., p. 92. 
cialmente Sixto V (1585-1590) y Clemente VIII e incorporadas en el conjunto de acciones que habían sido previstas para la celebración del Jubileo en 1600.

En un contexto en el que su sacralidad venía siendo cuestionada por la doctrina protestante, las políticas espaciales del martirio se desplegaron sobre la sacralidad indiscutible de una geografía subterránea que permitía postular la sacralidad de la geografía católica en general, compuesta de iglesias, objetos e imágenes y reliquias, integrados ahora en una unidad, en un todo constituyente. En las catacumbas la Iglesia no encontró solamente rastros de un pasado glorioso, también las claves de un futuro trascendente. La magnificencia de los espacios del ayer exigía una magnificencia equivalente en los espacios de la religiosidad del presente, una correspondencia que operaría como cimiento y cemento de los proyectos arquitectónicos y urbanos impulsados por Sixto $\mathrm{V}^{41}$

La emergencia de la sacralidad de espacios y objetos como condición "verdadera" explica la importancia que martirologios católicos como el de Verstegan ${ }^{42}$ atribuían a la figura de la profanación. Llevadas a cabo por los protestantes, las prácticas de profanación de imágenes y templos eran sumergidas en un campo de significación mayor en el que se postulaba, de manera implícita, que las profanaciones se ejercían contra una unidad compuesta tanto de los espacios sagrados de los primeros mártires como de las imágenes e iglesias del presente. Frente a la evidencia de las catacumbas, el cuestionamiento a la sacralidad de los símbolos adquiriría nuevos sentidos.

Con la celebración del Jubileo, bajo el mandato de Clemente VIII, se emprendió la renovación de varias iglesias en Roma con un plan iconográfico en el que tuvo un rol importante la exaltación del martirio de los más grandes santos de los primeros siglos. Con este criterio fueron renovadas las iglesias de los Santos Nereo y Aquileo (1600), San Apolinar (15801588), San Stefano Redondo (1582) y la iglesia de San Vitale (1596 -1603) cuya fachada, de acuerdo a Rodríguez de Cevallos ${ }^{43}$ fue decorada con instrumentos de martirio.

Una de las características del conjunto de obras realizado en cumplimiento de este plan iconográfico fue el contraste retórico. Entre otros, este contraste se lograba ya asociando sujetos y objetos de naturaleza diferente (ángeles cargando instrumentos de tortura) ya, oponiendo la forma (empleo de luces neutras, colores pastel, claros y suaves, formas armoniosas) al fondo (la crueldad, lo truculento, ver Figura n. 2). Más que la santidad de los ángeles o lo horrendo de los instrumentos de tortura, con el contraste y la oposición se propone un tercer mensaje: la dimensión sagrada del martirio, su aceptación como un destino divino.

A través de la representación combinada de escenarios, objetos y protagonistas, las imágenes evidencian una tortura institucionalizada por el aparato disciplinario del Imperio Romano. La máquina empleada, las autoridades intervinientes y el personaje oficiante, dan

\footnotetext{
${ }^{41}$ LABROT, Gérard. L'image de Rome: une arme pour la Contre-Réforme, 1534-1677, op. cit., p. 77.

${ }^{42}$ VERSTEGAN, Richard. Théâtre des cruautés des hérétiques de notre temps, op. cit.

${ }^{43}$ RODRÍGUEZ G. DE CEBALLOS, Alfonso. El mártir, héroe cristiano. Los nuevos mártires y la representación del martirio en Roma y en España en los siglos XVI y XVII, op. cit., p. 89.
} 
cuenta de prácticas de tortura que se llevan a cabo con técnicas establecidas y un orden ceremonial. Aunque en un segundo plano, la escena de tortura es dominada por un ángel "testigo" en la parte central superior; a los costados, dos querubines simulan sostener el retablo. La coexistencia entre personajes profanos y sagrados sugiere la sacralidad del acto de martirio dando lugar a una realidad en la que coexisten lo visible y lo invisible, lo trascendente y lo terreno. El conjunto se ubica en un escenario interno rodeado por una columnata; a lo lejos, se dibuja la silueta de la ciudad, entre el interior y el exterior, la muchedumbre encabezada por notables se suma como testigo al espectáculo.

\section{Figura n. 2}

Tortura de San Vitale. "S Vitalis. Equuleo Torquetur" Agostino Ciampelli (1562-1630). Basílica de San Vitale, Roma, 1595.

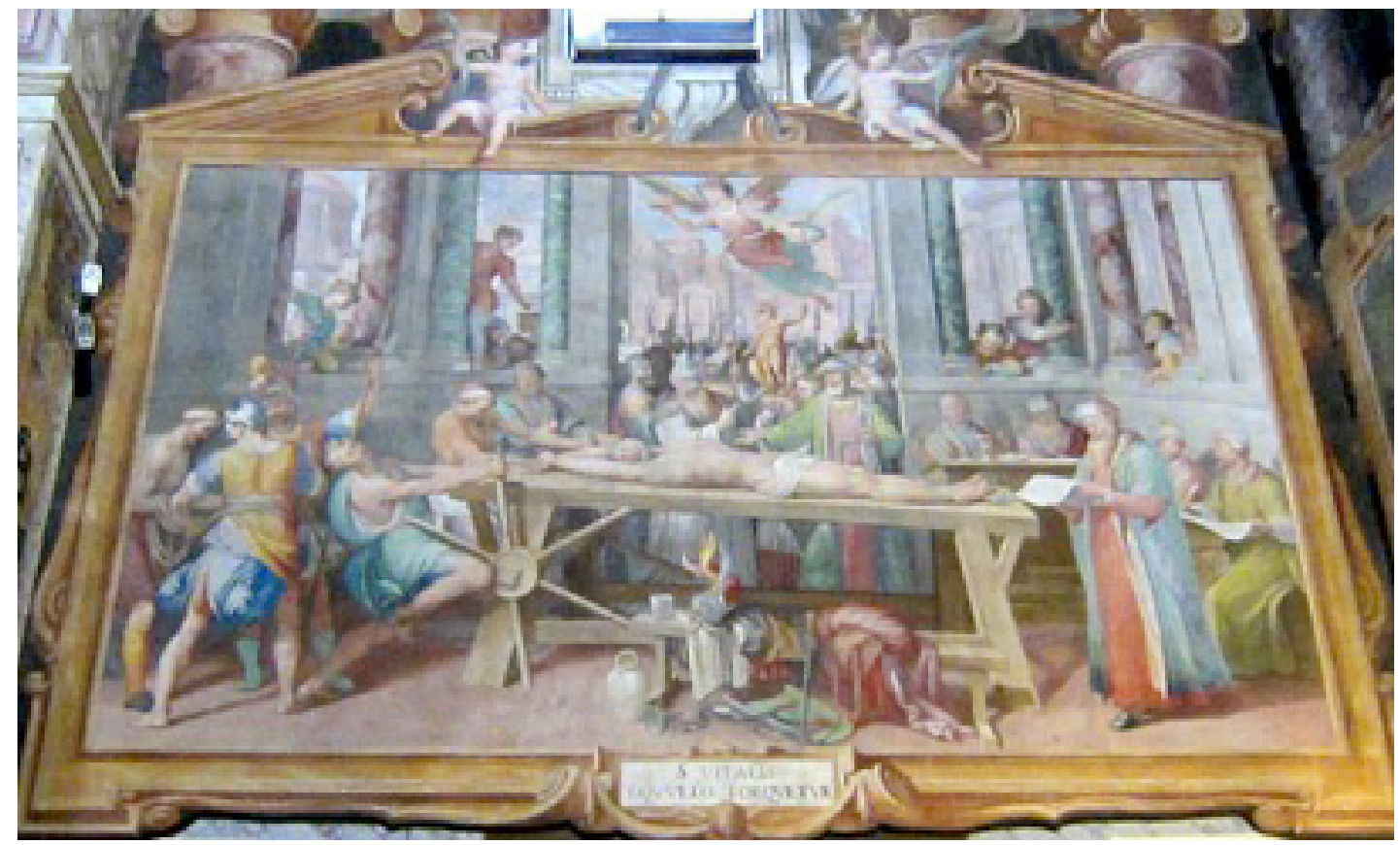

El fresco 'El Martirio de Bartolomé' (Figura n. 3) me permite señalar una segunda característica que Freedberg ${ }^{44}$ refiriéndose a obras similares, ya había identificado. La presencia de significados implícitos, escondidos o subconscientes. Aunque 'El Martirio de Bartolomé', es una expresión más de la célebre escena, representada varias veces, del santo siendo desollado, también hace referencia a otro evento de la realidad más cercana para el observador contemporáneo a la realización de la obra. El evento en cuestión tuvo lugar, apenas unos años antes a la elaboración de la pintura en el famoso cerco de la ciudad chipriota de Famagosta, hasta entonces en manos venecianas, por parte de un ejército otomano bajo las

${ }^{44}$ FREEDBERG, David. The hidden god: image and interdiction in the Netherlands in the sixteenth century, op. cit., p. 143. 
órdenes de Mustafa Bashaw. En 1571, rompiendo los términos establecidos para la rendición de Famagosta, Mustafa ordenó desollar vivo y martirizar al comandante veneciano de la fortaleza, Marc Antonio Bragadino, y a todos los cristianos que permanecían en la ciudad..$^{45} \mathrm{El}$ vínculo entre los dos episodios que se efectiviza mediante la obra puede establecerse en razón de las similitudes en las formas del martirio (Bartolomé y Bragadin siendo desollados), la actitud de los sufrientes (abnegación, valentía, fe), la violencia como espectáculo público y su representación, y la confrontación entre cristianos e "infieles" representados en el personaje situado a la izquierda del protagonista.

Figura n. 3

El Martirio de San Bartolomé.

"Il Pomarancio". Iglesia de Nereo y Aquileo, Roma, 1580.

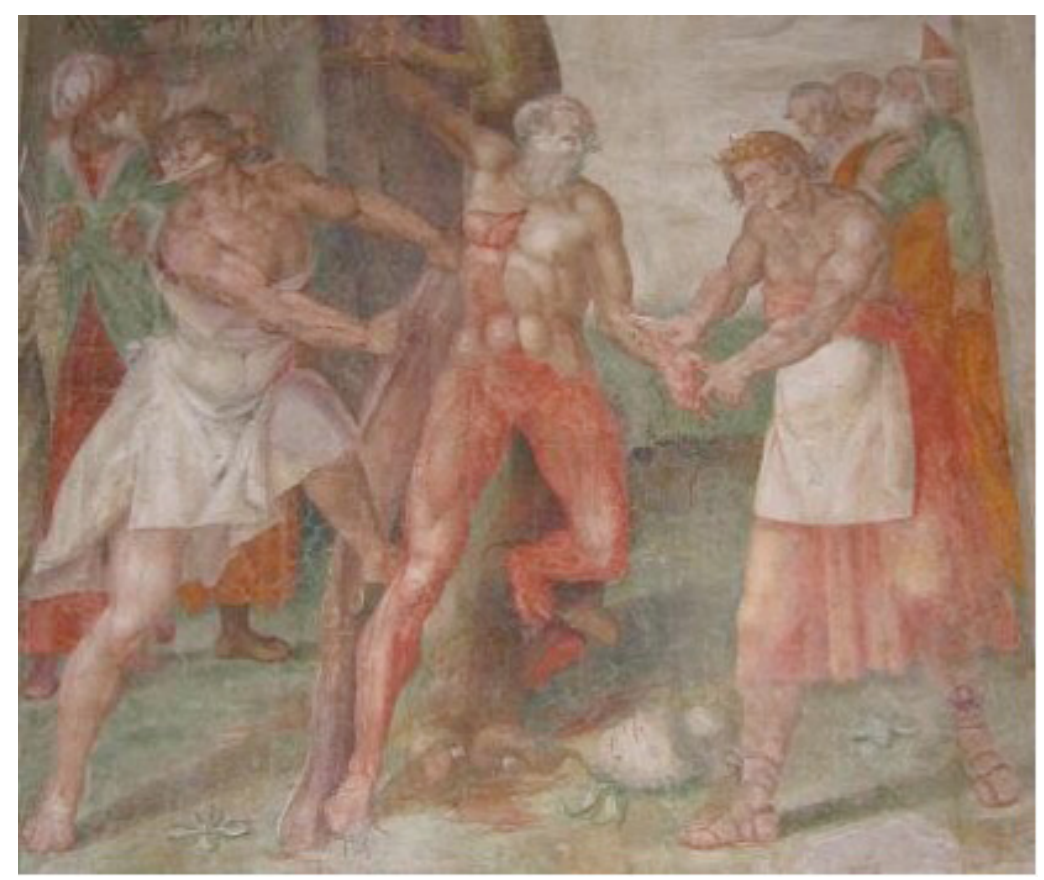

${ }^{45}$ Cf. RALSTON CAWLEY, Robert. George Gascoigne and the Siege of Famagusta quick view. Modern Language Notes, v. 43, n. 5, p. 296-300, 1928. p. 299; Ver también PARUTA, Paulo. The history of Venice; likewise the wars of Cyprus, wherein the famous sieges of Nicossia, and Famagosta, and Battel of Lepanto are contained. SF. p. 126. URL: <http://quod.lib.umich.edu/e/eebo/A56527.0001.001/1:8?rgn=div1;view=fu lltext>. Consultado: 24-03-2015. 
Siguiendo a Turner, ${ }^{46}$ Freedberg afirma que "los significados latentes - y hasta cierto punto los ocultos - de un signo dominante" en un contexto pueden ser descubiertos a partir de la exégesis de su significado en otro". ${ }^{47}$ Podríamos decir entonces que un cristiano víctima en Famagosta de la sevicia de los infieles, más que el martirio de San Bartolomé, es lo que ve el observador. Sin embargo, otra interpretación puede proponerse. Un suceso de conocimiento público del pasado reciente, mediante los juegos de las temporalidades, es puesto en relación con un acontecimiento - sagrado - de la historia profunda (los infortunios de Bartolomé), y el santo y el comerciante pasan a un segundo plano como si al adquirir un sentido trascendente se evaporasen. Mediante esos juegos, Bragadino se refleja en Bartolomé, adquiriendo profundidad histórica y dotando de identidad mística su desventura, y aquél en éste, postulando su pertinencia para entender los acontecimientos del presente. El cuadro pues, no es acerca de un hombre siendo desollado; es sobre la continuidad histórica de las formas del martirio, sobre el martirio como práctica religiosa trascendente y la identidad entre términos al interior de una relación estructural:

INFIELES : MARTIRIO : SAN BARTOLOMÉ :: BRAGADINO : MARTIRIO : INFIELES.

Contraste retórico, carácter institucionalizado de la tortura, ubicación a medio camino entre la representación de lo real y la representación de las alegorías, mensajes cifrados, juegos de las temporalidades son cinco características del conjunto de obras realizados en cumplimiento del plan iconográfico promovido por Baronio. En Roma, en la última década del siglo XVI, además de la celebración del Jubileo en 1600, en este conjunto de obras influyó el entusiasmo por los mártires y la figura del martirio. Nos referiremos ahora a algunos ejemplos del género específico del martirio.

\section{El ciclo de los mártires}

Durante la segunda mitad del siglo XVI, la expansión de la industria editorial generó una distribución cada vez más amplia de obras clásicas, atlas, y textos religiosos que poco a poco transgredió los límites tradicionales de circulación, restringida a la nobleza y al clero. Como vimos, la Reforma Protestante y las disputas por la supremacía religiosa generaron numerosas tensiones y conflictos. En este marco se publicaban obras como las de Acosta ${ }^{48} y$

\footnotetext{
${ }^{46}$ TURNER, Victor. La selva de los simbolos. Buenos Aires: Siglo XXI, 1999.

${ }^{47}$ Cf. FREEDBERG, David. The hidden god: image and interdiction in the Netherlands in the sixteenth century, op. cit., p. 133-153.

${ }^{48}$ ACOSTA, José de. Historia natural y moral de las Indias. Alicante: Biblioteca Virtual Miguel de Cervantes, 1999 [1590].
} 
De Las $\operatorname{Casas}^{49}$ en las que, entre muchos otros aspectos, se planteaba el tema de la naturaleza de la violencia. Las discusiones metafísicas del Descubrimiento, los conflictos por la hegemonía religiosa y la expansión de la cultura del martirio, configuraron un escenario en el que visiones contrapuestas del mundo estaban en disputa y en el que las políticas del martirio ocupaban un lugar fundamental.

Las representaciones del martirio habían sido incorporadas al proceso formativo de los novicios con una voluntad pedagógica y ejemplarizante. La intensidad con la que este tipo de espacios fueron edificados hace recordar el impuso que la actividad edilicia adquirió durante el pontificado de San Pascual $(817-824)^{50}$ en que se produjo un traslado masivo de reliquias desde las catacumbas y se realizaron algunos murales concernientes al martirio presumiblemente para celebrar tal evento (Osborne 1985, p. 293).

Ubicados en forma de murales en conventos e iglesias, las representaciones del martirio transformaban el espacio cotidiano de aislamiento, educación y ejercicios espirituales. Efectivamente, la Compañía de Jesús, creada apenas unas décadas antes (1539), tuvo un gran protagonismo en la consolidación de la "cultura del martirio". Durante las dos últimas décadas del siglo XVI, bajo la égida jesuita al menos siete ciclos de mártires serían realizados en iglesias romanas. En 1582 por ejemplo, los jesuitas húngaros encargaron a tres artistas, los italianos Niccolò Circignani, Mateo de Siena y Antonio Tempesta, la intervención de la iglesia de San Stefano Redondo en Roma, apenas tres años después de haber sido sucedido a los padres paulinos en la administración del lugar. En 1580 el Colegio Húngaro se fusionó con el Germánico, para acoger a novicios de diferentes regiones del por ese entonces convulsionado imperio austrohúngaro. La elección de los lugares en los que se ubicarían tales representaciones dialogaba con una geografía marcada por actos de consagración; San Stefano Redondo había sido edificada en el lugar de una iglesia cristiana primitiva construida en el Siglo IV en honor a San Esteban, primer mártir cristiano. Desde el siglo VII en que, como se anotó, muchas reliquias y restos fueron trasladados de las catacumbas a las iglesias, la iglesia albergaba los restos de los proto-mártires Primo y Feliciano. ${ }^{51}$

\footnotetext{
${ }^{49}$ DE LAS CASAS, Fray Bartolomé. Breve relación de la destrucción de las indias occidentales. México: Ontiveros, 1822 [1552].

${ }^{50}$ OSBORNE, John. The Roman Catacombs in the Middle Ages, op. cit., p. 292.

${ }^{51}$ Sitio internet de la Iglesia de San Stefano Redondo. URL: <http://www.santo-stefano-rotondo.it/index. php?option=com_content\&view=article\&id=1\&Itemid=5\&lang=it $>$. Consultado: 17-03-2015. Ver también OSBORNE, John. The Roman Catacombs in the Middle Ages, op. cit., p. 286. Una selección de imágenes de los frescos puede ser vista aquí. Fotos: <http://panoramy.zbooy.pl/gallery/rzym-santo-stefano-rotondo-3/20120224-124624-4495-raw5d.jpg/e>. Consultado: 2-04-2015.
} 
Figura n. 4

Iglesia de Santo Stefano Rotondo, Planta y elevación del edifício.

La planta del edificio, de tres círculos concéntricos, evoca la basílica del Santo Sepulcro de Jerusalén. Posee una columnata circular de 22 columnas jónicas. El conjunto está dominado por un altar central en recuadro octagonal sobre el que se representan episodios de la vida de san Esteban, obra de Niccolò Circignani, llamado Il Pomarancio (1517-1596).
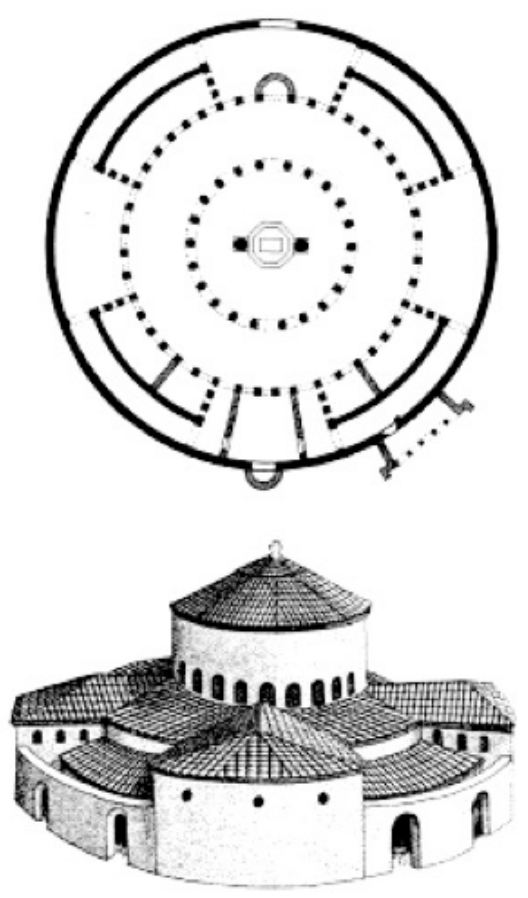

Fuente: Arquitectura Paleocristiana. ${ }^{52}$

En el muro envolvente del ambulatorio, Circignani elaboró un conjunto de treinta y un frescos, cada uno encuadrado por columnas de ladrillo (Figuras n. 5 y n. 6). "El ciclo de los Mártires" representa diferentes escenas de martirio ocurridas a lo largo de 400 ańos del Cristianismo, el todo presidido por la imagen de Cristo en el Calvario. ${ }^{53}$ En 1584 Tempesta realizaría otros dos frescos complementarios, el primero hacía alusión a la masacre de los inocentes, el segundo a la virgen de los dolores. El conjunto de los frescos permitía incorporar las historias de los mártires en las oraciones y meditaciones de los novicios constituyendo el escenario de prácticas de la memoria del martirio. A través de la evocación de los sufrimientos soportados en el nombre de Cristo, las obras pretendían preparar a los novicios para

52 URL: <http://architetturapaleocristiana.blogspot.com.ar/2012/09/la-chiesa-di-santo-stefano-rotondo. html>. Consultado: 2-04-2015.

${ }^{53}$ RODRÍGUEZ G. DE CEBALLOS, Alfonso. El mártir, héroe cristiano. Los nuevos mártires y la representación del martirio en Roma y en España en los siglos XVI y XVII, op. cit., p. 91. 
su misión de evangelización ${ }^{54}$ en un contexto en el que la ampliación del mundo a través de la expansión europea del siglo XVI daba lugar a una apertura mundial del campo misional y en el que el martirio ocupo un lugar protagónico. ${ }^{55}$

Figuras n. 5 y 6

Iglesia de San Stefano Rotondo, 2015. Roma.
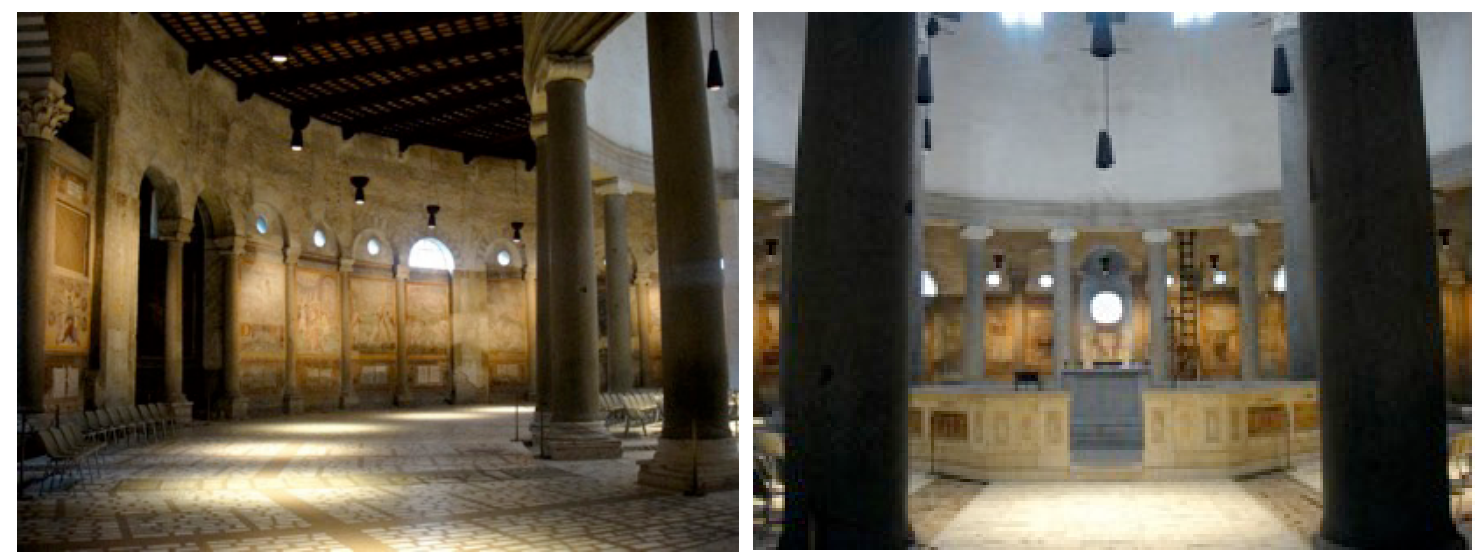

Foto: Simone diSanti, The Stefano Rome Tours Team.

Cada una de las pinturas de San Stefano Redondo representa un mártir o un grupo de mártires; en la parte inferior está acompańado de la descripción en latín e italiano de la forma en que el o los mártires fueron torturados, en qué circunstancias, cuándo y bajo el dominio de qué Emperador. La dimensión pedagógica del martirologio teatral fue complementada con letras en los frescos que orientaban la lectura y la interpretación (Figuras n. 7 y 8). El martirologio de San Stefano se vincula con los ejercicios espirituales de Loyola entre los que se destacan la "composición del lugar" como parte de la meditación espirituales y el drama como herramienta educativa de los novicios. ${ }^{56}$

\footnotetext{
${ }^{54}$ MONSSEN, Leif Holm. Rex Gloriose Martyrum: A Contribution to Jesuit Iconography. The Art Bulletin, v. 63 , n. 1, p. 130-137, 1981.

${ }^{55}$ JACQUELARD, Clotilde. Une catastrophe glorieuse: le martyre des premiers chrétiens du Japon, Nagasaki, 1597. e-Spania, n. 12. 2011. URL: <http://e-spania.revues.org/20808>. Consultado: 21-10-2013.

${ }^{56}$ ORDIZ VÁZQUEZ, Francisco Javier. El 'triunfo de los santos' y el teatro jesuita del siglo XVI en México, Anales de literatura hispanoamericana, n. 18, p. 19-28, 1989. p. 20.
} 
Figuras n. 7 y 8

Iglesia de San Stefano Rotondo, 2015. Roma
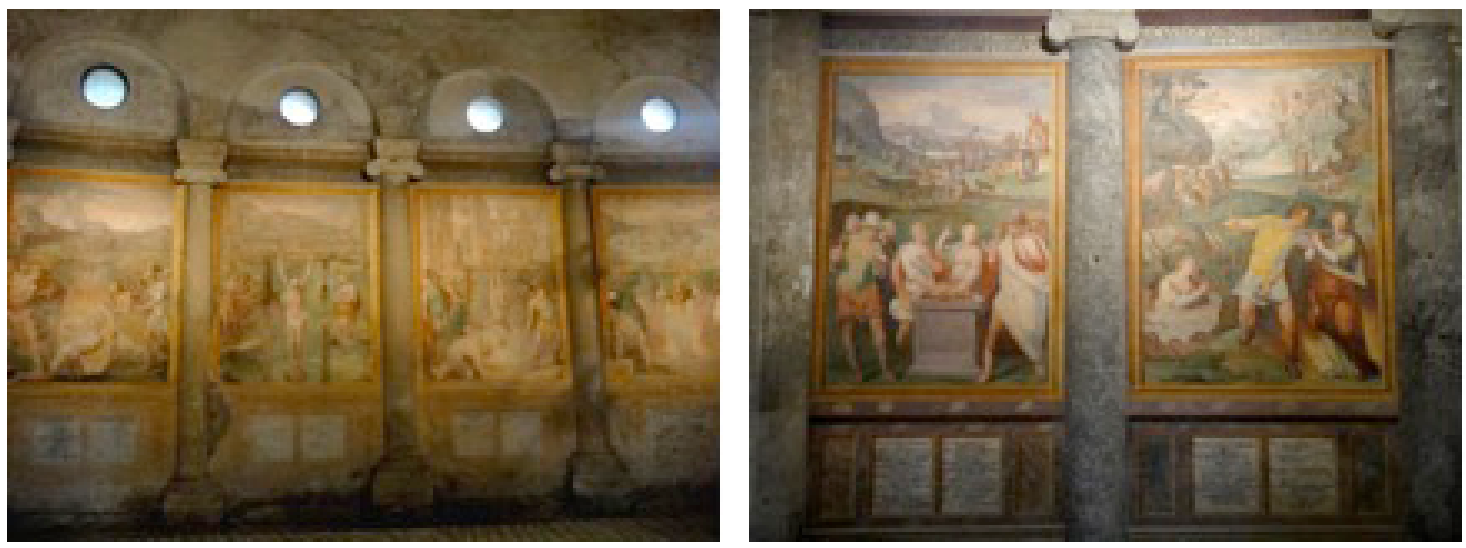

Foto: Simone diSanti, The Stefano Rome Tours Team

Siguiendo el orden de los martirios expresados en el ciclo de frescos del ambulatorio circular, el rito litúrgico termina en un mural localizado cerca de la puerta de la iglesia; un final de puntos suspensivos que sugiere a los novicios sumarse a la gloriosa sucesión de santos. ¿Hacia dónde irían los nuevos misioneros? Al dejar San Stefano Redondo, los novicios sabían que su nueva vida "posiblemente terminaría en un martirio similar al de los primeros cristianos". ${ }^{57}$ Otra pista puede encontrarse en Sanguinis martyrorum semen Christianiorum, una completa enciclopedia de jesuitas martirizados, organizada por continentes e ilustrada con 169 imágenes de escenas de martirio. ${ }^{58}$ La imagen (Figura n. 9) muestra la naturaleza de las batallas que enfrentaron los soldados de la Compañía al asumir al mundo entero como escenario de sus batallas, y a los infieles y a los herejes como sus enemigos.

\footnotetext{
${ }^{57}$ NOREEN, Kirstin. Ecclesiae militantis triumphi: Jesuit Iconography and the Counter-Reformation. The Sixteenth Century Journal, v. 29, n. 3, p. 689-715, 1998. p. 697.

${ }^{58}$ OSSWALD, Cristina. A iconografia do martírio na Companhia de Jesus entre os sécs. XVI e XVIII, op. cit., p. 1305.
} 
De LAS CATACUMBAS A LOS ÚlTIMOS CONFINES: VIOLENCIA, SENTIDO Y REPRESENTACiÓN EN LOS PERIPLOS DEL MARTIRIO

Carlos Arturo Salamanca Villamizar

Figura n. 9

Sanguinis martyrorum semen Christianiorum

La sangre de los mártires es la semilla de los cristianos. Grabador: Mathias Küssel

Se observa un jardín espiritual con cruces cuidadas floreciendo en el jardín y en la copa de los árboles, regadas con la sangre de los mártires jesuitas por asistentes espirituales. En la parte superior, un jesuita enarbola un libro, símbolo de la ciencia. Dromedarios y elefantes situados en la parte inferior y acompañados de un hombre con turbante y atuendos "orientales", sugieren la dimensión universal de la empresa del martirio.

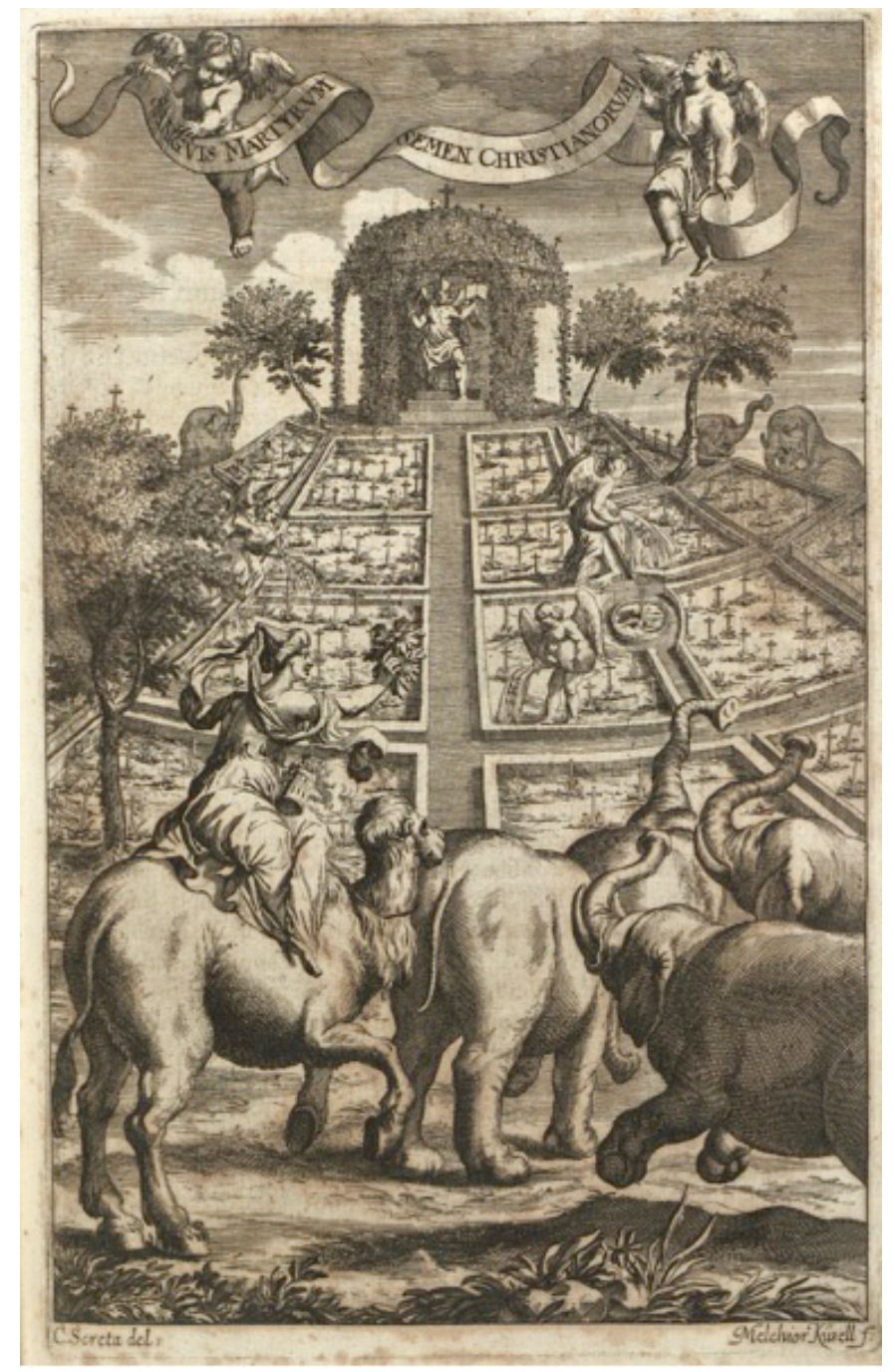

Fuente: TANNER, Mathias. $1675^{59}$

\footnotetext{
${ }^{59}$ Societas Jesu usque ad sanguinis et vitae profusionem. En Spiritual Journeys. Books Illustrating the First Two Centuries of Contemplation and Action of the Society of Jesus. Prague: Typis Universitatis Carolo-Ferdinandeae per Joannem Nicolaum Hampel factorem, Amberes, 1675. Fuente: <http://libraries.slu.edu/a/ digital_collections/spiritual-journeys/afterword.html>. Consultado: 1-12-2013.
} 


\section{El Triunfo de una Iglesia Militante}

En 1583, apenas un año después de la realización de los frescos de San Stefano Redondo, el grabador Giovanni Battista de'Cavalieri (1526-1597), publicó el Triunfo de la Iglesia Militante $^{60}$. Se trata de un pequeño libro que reproducía los frescos bajo forma de grabados, acompañándolos de información, letanías, oraciones y otros ejercicios religiosos. Diversos autores han subrayado la importancia de las impresiones (sus estilos, sus adaptaciones en función de las audiencias, sus formas de circulación) tanto en el estatus de las imágenes como en su difusión. ${ }^{61}$ En un contexto en el que la Compañía impulsaba un sistema propio y global para todas las instituciones educativas (el Ratio Studiorum), el EMT tuvo un gran impulso editorial representado en 4 ediciones durante los seis ańos siguientes a su publicación. ${ }^{62}$

La imagen de San Esteban incluida en el EMT (Figura n. 10) presenta cuatro escenas: en primer plano San Esteban, en actitud serena, de rodillas y vestido con una túnica, es apedreado por tres hombres descalzos y con el torso desnudo; a la izquierda algunos apóstoles son golpeados mientras que a la derecha se presenta la escena de decapitación de San Jaime por un guardia en frente de dos testigos. En la parte superior derecha, el martirio es observado por Jesucristo. Son estos los rastros de una técnica que se difundiría ampliamente durante el s. XVII ${ }^{63}$. La combinación de texto de imagen, la división del espacio visual del grabado en escenas, la identificación con letras de cada una de los eventos descritos, y el hacer explicito cada detalle de la escena.

${ }^{60}$ CAVALIERI, Giovanni. Ecclesiae Militantis Triumphi. Roma, 1583.

${ }^{61}$ Ver, por ejemplo, FREEDBERG, David. Prints and the status of images in Flanders. In: ZERNER, Henri (Ed.). Le Stampe e la diffusione delle Immagini e degli Stili (Atti del XXIV Congresso Internazionale di Storia dell'Arte) 1979, v. VIII, Bologna, 1983, p. 39-44.

${ }^{62}$ NOREEN, Kirstin. Ecclesiae militantis triumphi: Jesuit Iconography and the Counter-Reformation, op. cit., p. 699.

${ }^{63}$ Acerca de esta técnica, Cf. FREEDBERG, David. Prints and the status of images in Flanders, op. cit., 46 y FABRE, Pierre Antoine. Ignace de Loyola. Le lieu de l'image : Le problème de la composition de lieu dans les pratiques spirituelles et artistiques jésuites de la seconde moitié du XVIe siècle. París: Vrin/EHESS, 1992. 
Figura n. 10

Escena de San Esteban, reconocido como el primer mártir cristiano. Grabador: Giovanni B. Cavalieri.

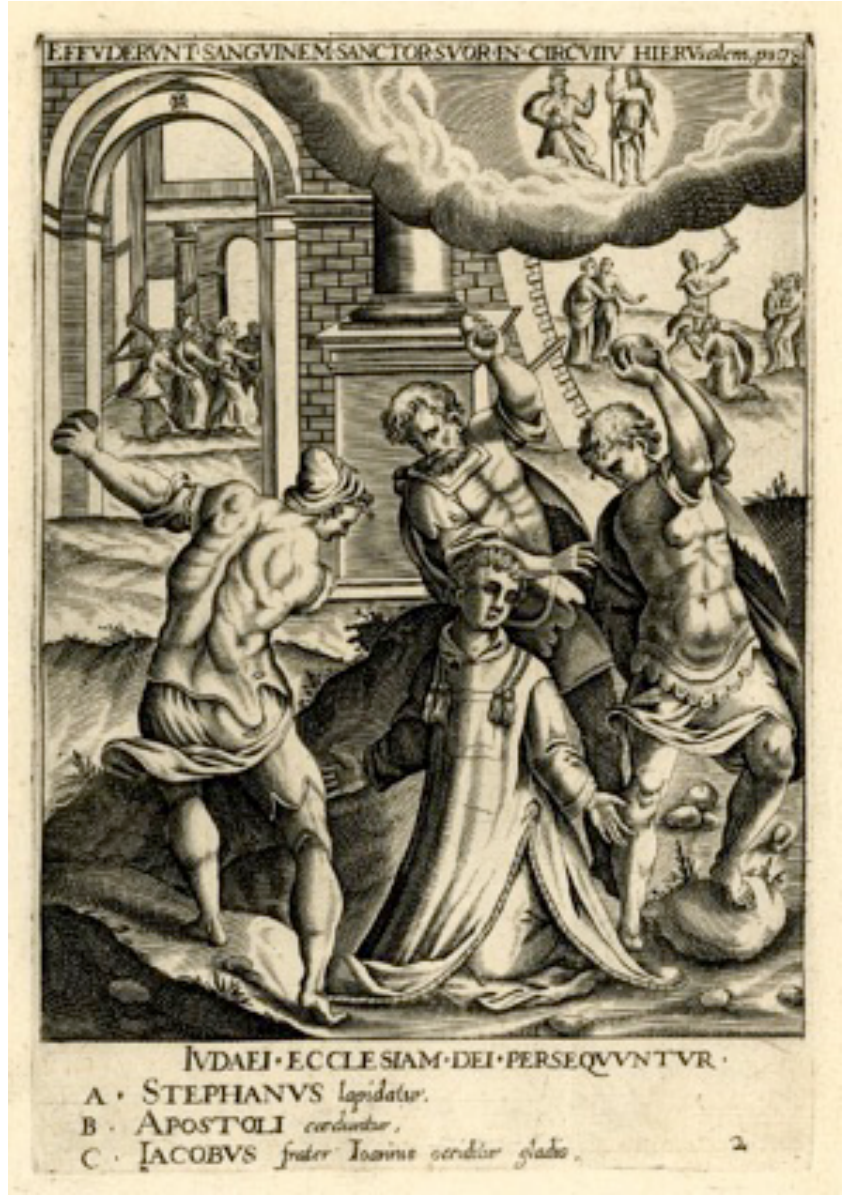

Fuente: CAVALIERI, Giovanni Batista. Ecclesiae Militantis Triunphi. op cit, placa 2.

En estos contextos la legitimidad de los mensajes no dependería de su originalidad, pues esta misma parecía imposible en razón de los múltiples agentes que intervenían en su producción. Artistas, grabadores o editores no tenían un control total del proceso de producción y más bien, eran parte de conjuntos heterogéneos en donde la copia, la cita, la síntesis, y la edición primaban por sobre el acto creativo puro y la estricta autoría individual. ${ }^{64}$ Aquí la noción moderna de autor es inestable, no sólo por aquello que se entiende por creación individual, sino por los varios agentes que participan en su producción.

En diálogo con la escenografía del martirio de Stefano Redondo, el EMT reforzaba el uso del martirio como camino a la gloria divina y ejemplo a seguir por los jóvenes novicios,

\footnotetext{
${ }^{64}$ MUKERJI, Chandra. Printing, cartography and conceptions of place in Renaissance Europe Media. Culture \& Society, v. 28, n. 5, p. 651-669, 2006. p. 652.
} 
intensificaba la relación entre los murales introduciendo letanías y pequeñas oraciones para los mártires, y breves frases con el significado espiritual de cada fresco, creando un orden litúrgico que acompañaba el orden espacial en el que están dispuestas las pinturas, dotando al novicio de un instrumento que ampliaba su repertorio interpretativo de los frescos. A su vez, el EMT vehiculizaba prácticas litúrgicas ordenadas en rutinas diarias, semanales y anuales que se articulaban a las conmemoraciones, festividades y otras fechas importantes del calendario ritual cristiano.

En el movimiento pendular entre lo individual y lo colectivo, entre el estar en el "Teatro" de San Stefano Redondo y el ejercicio espiritual a través de la evocación del Teatro viabilizada por el EMT, se percibe la "Composición del lugar", uno de los ejercicios espirituales de Loyola centrado en la imaginación de un locus, la configuración imaginaria de una escena, y la reconstrucción imaginaria de un orden.

Los principios inherentes al ejercicio espiritual, darían lugar a una serie de acciones como la conformación de las misiones jesuíticas en Paraguay en las que se asumía que determinada organización espacial de las misiones permitiría la imposición de una nueva concepción de sociedad; en esta línea, la urbanidad en las misiones era frecuentemente descrita como una escena teatral, la plaza central como el escenario principal y eje de la vida ritual, y los castigos corporales públicos una acción educativa ejemplarizante. ${ }^{65}$

El EMT era útil para los novicios no sólo en función de la acción de intermediación con los frescos de San Stefano Redondo. Después de haber pasado por el ciclo formativo, los jóvenes sacerdotes partían a la experiencia de misionarización, unos en sus lugares de origen en otras partes de Europa, otros en los territorios de frontera de un mundo en expansión. Por intermedio del EMT los novicios enfrentados a la hostilidad de herejes e infieles, llevarían consigo tres certezas divinas procedentes de la escenografía de la memoria de San Stefano Redondo: una primera, temporal (sus sufrimientos se insertaban en una larga historia de glorificación), una segunda, socializante (sus penurias serían ejemplos para otros), y una tercera, trascendente (sus martirios serían glorificados). Lejos de quedar encerrada en los muros de las iglesias, la memoria de los mártires fue utilizada en el proyecto de expansión universal de la Compañía con un propósito que quedaría consignado en los Anales del Colegio inglés en Roma:

Hemos distribuido este trabajo [el EMT] por todas partes, incluso en las Indias, para que la infamia de estas desastrosas persecuciones, la frenética rabia de los heréticos, la firmeza inconquistable de los Católicos, puedan ser conocidas en todas partes. ${ }^{66}$

\footnotetext{
${ }^{65}$ WILDE, Guillermo. The Political Dimension of Space-Time Categories in the Jesuit Missions of Paraguay (17th and 18th Centuries). In: MARCOCCI, Giuseppe; DE BOER, Wietse; MALDAVSKY, Aliocha y PAVAN, Ilaria (Eds.). Space and Conversion in Global Perspective. Leiden: Brill, 2014. p. 175-213.

${ }^{66}$ FOLEY, Henry. Records of the English Province of the Society of Jesus. Londres: Burns ans Oates, 1880, 6:83. In: NOREEN, Kirstin. Ecclesiae militantis triumphi: Jesuit Iconography and the Counter-Reformation, op, cit., p. 698, mi traducción.
} 
La coherencia y sentido del sistema representacional se mantenía a través de juegos de correspondencia entre imágenes, orden y convenciones. La continuidad entre el dispositivo escenográfico y el impreso, no excluía la posibilidad de realizar ajustes para responder más adecuadamente a los nuevos circuitos de circulación. Sin embargo, las imágenes de San Stefano Redondo no fueron reproducidas de manera idéntica en el EMT. Por ejemplo, el grabado "Martyrs du temps des empereurs Maximin et Licinius" que hace parte de la edición de 1583, (Placa 28, p. 15) aparece en la edición de 1598, aunque invertida en sentido horizontal. ${ }^{67}$ Asimismo, en el EMT no fueron incluidos los frescos de los Santos Inocentes ni el de la Virgen de los Dolores realizados por Tempesta en San Stefano Redondo ${ }^{68}$ A pesar de los cambios de forma, soporte, formato y escala, la continuidad entre el ciclo de los mártires y la publicación no es puesta en duda; esto demuestra que diferentes elementos del conjunto representacional podían cambiar sin afectar al conjunto mismo. ${ }^{69}$

El Ecclesiae Militantis Triunphi no fue el único caso en que los dispositivos iconográficos del martirio realizados en las iglesias fueron reproducidos a gran escala en forma de grabados introducidos en martirologios. Tres años después de la intervención iconográfica en la Iglesia de San Apollinari en 1583 se publicó el Beati Apollinaris primi. En el mismo año, Circignani realizó los frescos de la iglesia San Tommaso di Canterbury del colegio inglés en Roma que describían el martirio de los católicos en Inglaterra, iniciando con el apóstol Pedro y terminando con la muerte del católico inglés Richard Thirkeld en York en el mismo año de 1583, vinculándolos a todos en una sola y misma sucesión. Al año siguiente fue publicada en Roma la Ecclasiae Anglicanae Trophea (Figura n. 11) que reproducía los frescos del Colegio.

\footnotetext{
${ }^{67}$ NOREEN, Kirstin. Ecclesiae militantis triumphi: Jesuit Iconography and the Counter-Reformation, op. cit., p. 712.

${ }^{68}$ Ibid, op. cit.

${ }^{69}$ FABRE, Pierre-Antoine. Les Visions d'Ignace de Loyola dans la diffusion de l'art jésuite. MLN, v. 114, n. 4, p. 816-847, 1999. p. 817.
} 
Figura n. 11

Ecclesiae anglicanae trophaea

Grabador: Giovanni B. Cavalieri.

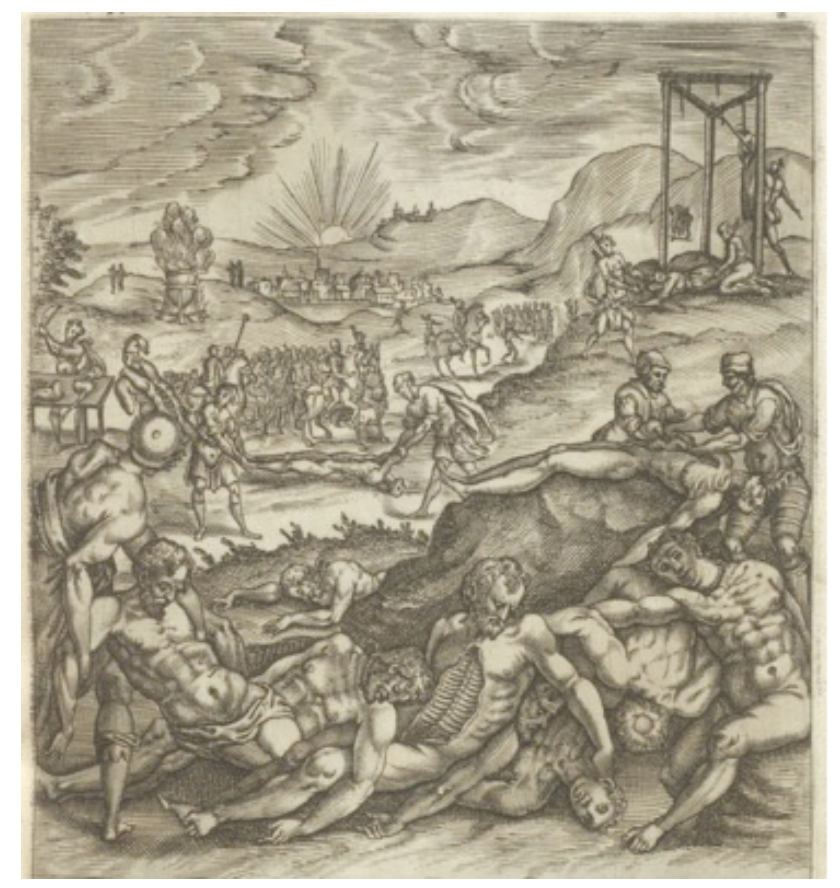

Fuente: GRASSI, BARTOLOMEO. Ecclesiae Anglicanae Trophaea. Roma, 1584.

La capacidad exhibida por Cicignano y Cavalieri para inscribir los acontecimientos más recientes en una historia de larga duración, se vio posibilitada por el formato al que recurrían. Recordemos también que en 1583, un año antes, era publicada la cuarta edición del libro de los mártires de Foxe que tenía una orientación profundamente anticatólica. Las obras de Cicignano y Cavalieri como la obra de Foxe compartían un doble propósito aunque contrario: el despliegue de una estrategia articulada de divulgación/ expansión de una historia larga y gloriosa escrita con la sangre de los mártires articulada al presente, la construcción y evocación de una geografía santificada con los actos del martirio.

Durante estos años la Compañía de Jesús desarrollaría un inmenso repertorio de martirologios, grabados y otras mediaciones de memoria que convertían la crueldad sufrida por sus mártires en una acción "verdaderamente triunfante". ${ }^{70}$ En 1608 el coloniense Johannes Bussemacher realizó el grabado "Effigies et Nomina Quorundam e Societate Iesu" (Figura n. 12). El grabado, dedicado a Johannes Hartmann, aparentemente realizado en una hoja separada, muestra la esfinge de 102 mártires jesuitas muertos entre 1549 y 1606, ordena-

\footnotetext{
${ }^{70}$ OSSWALD, Cristina. A iconografia do martírio na Companhia de Jesus entre os sécs. XVI e XVIII, op. cit., p. 1301-1313. p. 1303.
} 
dos por orden cronológico y acompañados por textos de Pedro Ribadaneira. De acuerdo a Osswald, ${ }^{71}$ los mártires están "acompañados por la palma del martirio y el instrumento (no necesariamente correcto) del mismo martirio”. Un año después de ésta publicación San Ignacio de Loyola sería beatificado.

\section{Figura n. 12}

Effigies et Nomina Quorundam e Societate Iesu.

Colonia, 1608. Grabador: Johannes Bussemacher

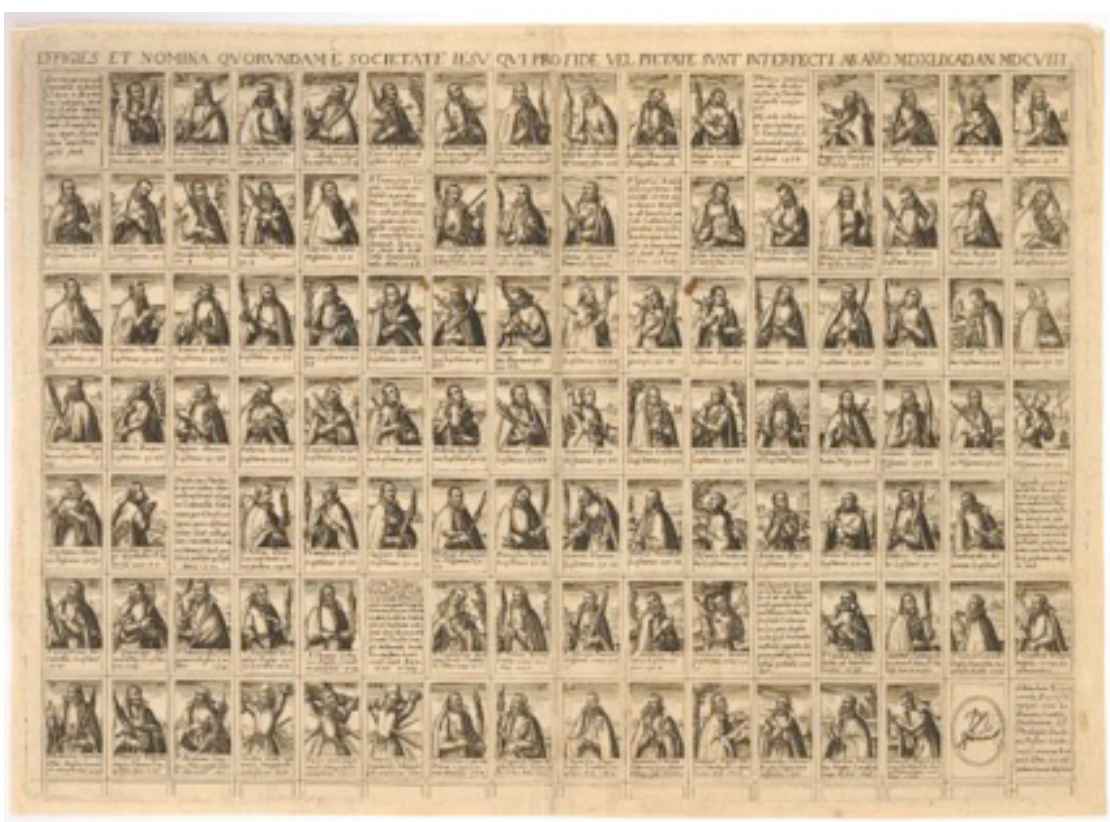

Fuente: The British Museum

En el siglo XVII, la iconografía jesuita y la expansión de la Compañía se vieron impulsadas por la celebración del centenario de la Compañía en 1640 y del centenario de la muerte de San Ignacio en 1656; celebraciones que fueron precedidas por su beatificación (1609) y su canonización (1622). Las narrativas del martirio se expandieron en todos los rincones de la extensa geografía jesuítica y la figura de los mártires se inscribió en distintos espacios en el territorio americano. ${ }^{72}$ En una descripción de una de las misiones del Paraguay en las que vivió entre 1691 y 1733, el jesuita Anton Sepp describió que, en su austeridad, la misión solo contaba con tres imágenes, dos de las cuales eran de mártires, una de San Juan Bautista - decapitado por Herodes, y otra de San Francisco de Javier - martirizado en China

\footnotetext{
${ }^{71}$ Ibid., p. 1304.

${ }^{72}$ BARCELOS, Artur. Os jesuítas e a ocupação do espaço platino nos séculos XVII e XVIII. Revista Complutense de Historia de América, n. 26, p. 93-116, 2000.
} 
en $1552^{73}$. Estas imágenes son indicios del poderoso vínculo que existía entre la vocación misionera y la búsqueda de la muerte al servicio de la fe ${ }^{74}$ por lo que en Espańa no dejaban de embarcarse voluntariamente en busca del martirio. Al respecto Page habla de 36 mártires solamente en el Paraguay siendo los únicos canonizados González de Santa Cruz, Alonso Rodríguez y Juan de Castellanos. ${ }^{75}$ La expansión de las imágenes del martirio a todos los rincones del mundo colonial se correspondió con la incorporación de elementos de la fauna y la flora no-europeas en las escenas de los martirios jesuitas, instaladas en lugares frecuentados por novicios. ${ }^{76}$ Es decir, las representaciones del martirio incorporaban ya el paisaje de lo extrańo, lo adverso y lo distante como escenario de una narrativa actualizada.

Los mártires viajarían a tierras paganas además de las imágenes en impresiones, misarios y estanpillas, a través de otras mediaciones. En 1578 Gregorio XII envió al Colegio de San Ildefonso de México algunas reliquias de mártires, extraídas de las catacumbas. El tesoro arqueológico fue recibido en noviembre del mismo año con una pieza teatral sobre los primeros cristianos de fastuosa puesta en escena, ${ }^{77}$ materializando la tradición jesuita del teatro como medio de propaganda religiosa ${ }^{78}$ que tendría continuidad en México, ${ }^{79}$ Brasil $^{80}$ y en varios otros lugares de América Latina. ${ }^{81}$

Como afirma Fabre, con su desembarco, las reliquias generarían un desafío a los jesuitas del Colegio: convertir lo antiguo (las reliquias) en la manifestación de un orden nuevo, y hacer de lo nuevo (la conquista espiritual de Nueva España) la manifestación de una larga y antigua tradición (la historia cristiana). ${ }^{82}$ Fabre también afirma que durante el siglo XVI,

\footnotetext{
${ }^{73}$ WILDE, Guillermo. The Political Dimension of Space-Time Categories in the Jesuit Missions of Paraguay (17th and 18th Centuries), op. cit.

${ }^{74}$ GIUDICELLI, Christophe; RAGON, Pierre. Les martyrs ou la Vierge ? Frères martyrs et images outragées dans le Mexique du Nord (XVIème-XVIIème siècles). par. 2. Nuevo Mundo. Mundos Nuevos, 2005. URL: $<$ http://nuevomundo.revues.org/615>. Consultado: 18-11- 2013.

${ }^{75}$ PAGE, Carlos. Siete Ángeles. Jesuitas en las reducciones y colegios de la antigua Provincia del Paraguay. Buenos Aires: Paradigma Inicial, 2011. p. 43.

${ }^{76}$ OSSWALD, Cristina. A iconografia do martírio na Companhia de Jesus entre os sécs. XVI e XVIII, op. cit., p. 1303.

${ }^{77}$ ORDIZ VÁZQUEZ, Francisco. 'El triunfo de los santos' y el teatro jesuita del siglo XVI en México, op. cit., p. 19-28.

${ }^{78}$ SCHNITZLER, Henry. The Jesuit Contribution to the Theatre. Educational Theatre Journal, v. 4, n. 4, p. 283-292, 1952.

${ }^{79}$ ORDIZ VÁZQUEZ, Francisco. 'El triunfo de los santos' y el teatro jesuita del siglo XVI en México, op. cit., p. 22-26.

${ }^{80}$ WASSERMAN, Renata. The Theater of José de Anchieta and the Definition of Brazilian Literature. Luso-Brazilian Review, v. 1, n. 36, p. 71-85, 1999.

${ }^{81}$ LÓPEZ, Sebastián. Contrarreforma y Barroco. In: FAJARDO DE RUEDA, Marta. El espíritu barroco en el arte colonial. Bogotá: BLAA, 1981. p. 61-91. URL: <http://www.banrepcultural.org/blaavirtual/todaslasartes/ext/ext13.htm\#4a>. Consultado: 18-11-2013.

${ }^{82}$ FABRE, Pierre-Antoine. Reliquias Romanas en México, historia de una migración. In: WILDE, Guillermo (Ed.). Saberes de la conversión. Jesuitas, indígenas e imperios coloniales en las fronteras de la cristiandad. Buenos Aires: Sb, 2011. p. 205-224. p. 213.
} 
la procesión de las reliquias a través de la ciudad era presentada como "una forma de constituir la ciudad sagrada al interior de la ciudad profana", ${ }^{83}$ y aún el siglo XIX, se realizaban ceremonias que pretendían actualizar la ciudad recorrida por las reliquias presentadas ahora como objeto/evento constituyente de la joven nación en emergencia. ${ }^{84}$

Las imágenes del martirio se inscribieron también en iglesias y catedrales. En el colegio de los jesuitas de Salvador de Bahía construido entre 1683 y 1694 por ejemplo, fueron realizadas las efigies de veintiún hermanos y padres de la Compañía ${ }^{85}$ en el cielo raso de la sacristía. El mártir y la figura misma del martirio dieron lugar también a dramatizaciones. ${ }^{86}$ No obstante, dos elementos dificultaban el reconocimiento público del mártir: la ausencia de restos y la falta de testimonios. ${ }^{87}$ En busca de un reconocimiento que sólo podían encontrar en Roma a través de la canonización, los misioneros mártires americanos hacían el camino inverso desde tierras paganas en donde se entregaban con entusiasmo a la labor apostólica hacia las metrópolis y los centros de formación en busca de su beatificación, de honores en su tierra natal, o de convertirse en ejemplo para los novicios. ${ }^{88}$ Una vez canonizados, los mártires se sumarían al martirologio a través de mapas, grabados, publicaciones y ceremonias para continuar con un recorrido complementario y articulado al descrito con destino a las colonias con el objetivo de cumplir con el dispositivo ejemplarizante.

Este fue el caso de 26 cristianos capturados y crucificados después del naufragio en 1596 del galeón que los transportaba a Japón y que, durante su cautiverio, escribían cartas en las que escenificaban sus propios sufrimientos. El registro en el que circularían posteriormente buscaba la empatía de las audiencias europeas con las tragedias de los mártires y la empresa misionera en las colonias convertidas, las primeras en actualizaciones de la escena primordial de los primeros mártires y la segunda en una empresa universal y trascendente: "leyendo, usted compartirá el dolor, participará en su labor", decía una de éstas publicaciones, "en-

\footnotetext{
${ }^{83}$ Ibid., p. 216.

${ }^{84}$ Ibid., p. 217.

${ }^{85}$ DE MOURA SOBRAL, Luis. Pintura, santos y propaganda: la sacristía del antiguo colegio de los jesuitas de Salvador, Bahía. In: Territorio, Arte, Espacio y Sociedad, Actas III Congreso Internacional del Barroco Americano: Universidad Pablo de Olavide, Sevilla, 8 al 12 de octubre de 2001.

${ }^{86}$ Diversos autores han encontrado en la figura de los mártires en general y en las reliquias en particular, un campo fecundo para el análisis de las interacciones entre las sociedades indígenas y los actores coloniales. Entre otros: CASTELNAU-L'ESTOILE, Charlotte de. Compartir las reliquias. Indios Tupíes y jesuitas frente a los huesos de un misionero Chamán en el Brasil de inicios del siglo XVII. In: WILDE, Guillermo (Ed.). Saberes de la conversión. Jesuitas, indígenas e imperios coloniales en las fronteras de la cristiandad. Buenos Aires: SB, 2011. p. 225-250. MAXWELL Kenneth. The Spark: Pombal, the Amazon and the Jesuits. Portuguese Studies, n. 17, p. 168-183, 2001.

${ }^{87}$ GIUDICELLI, Christophe; RAGON, Pierre. Les martyrs ou la Vierge ? Frères martyrs et images outragées dans le Mexique du Nord (XVIème-XVIIème siècles). Nuevo Mundo Mundos Nuevos. par. 14, 2005. URL: http://nuevomundo.revues.org/615. Consultado: 10-11-2013.

${ }^{88}$ GÓMEZ-GÉRAUD, Maria Cristina. Le théâtre des premiers martyrs japonais: la leçon de théologie. In: LESTRINGANT, Frank; MOREAU, Pierre-François et al. Martyrs et Martyrologues. Revue de Sciences Humaines, n. 269, p. 175-187, 2003.
} 
contrará que la historia primitiva de los mártires está siendo representada y actualizada dignamente". ${ }^{89}$

El discurso franciscano sobre el martirio, aunque separado y a veces en tensión con el jesuita, se acercó al registro épico que impulsaba la idea del "ejército de Cristo" enfrentado a la "conquista espiritual”. A su vez, la memoria de los mártires franciscanos en Japón procuró la "analogía teleológica", facilitada por la crucifixión. ${ }^{90}$ Un juego que daría lugar a varias transfiguraciones: Nishizaka, la colina donde serían crucificados los mártires en el monte calvario, Pedro Bautista, padre de la iglesia japonesa franciscana en San Pedro, Kioto en la nueva Roma y los 26 crucificados en una versión actualizada de Cristo. ${ }^{91}$

La cartografía jesuítica del siglo XVIII en América retomó en varias ocasiones la cuestión del martirio. A modo de ejemplo pueden citarse el mapa de Cardiel (1760) del Paraguay, ${ }^{92}$ los trabajos cartográficos de Fritz (1707) en el Amazonas ${ }^{93}$ y el mapa de Machoni (1733) de las regiones chaqueńa y de Chiquitos. ${ }^{94}$ En estos mapas se localizan, entre otros, los sitios en que fueron martirizados los misioneros jesuitas y el pueblo en que doctrinaban". ${ }^{5}$ Estos acontecimientos localizados, junto con otros nodos de memoria espacializada como las misiones destruidas, saqueadas o desplazadas, extienden la geografía sagrada inaugurada con las catacumbas subterráneas romanas hasta los "últimos confines" a los que estaban destinados los misioneros en tanto continuadores de la empresa divina.

\section{Conclusiones}

Este trabajo ha sido más cartográfico que histórico y más sobre las representaciones de los acontecimientos que sobre los acontecimientos mismos. ${ }^{96} \mathrm{Me}$ he propuesto seguir las figuras polivalentes del mártir y del martirio en su circulación a través de grabados, mapas y otras mediaciones, en un mundo en expansión gracias a los adelantos científicos y una mayor intensidad en los viajes y las exploraciones.

\footnotetext{
${ }^{89}$ FROES, Louis. Histoire de la glorieuse mort de vingt six chrestiens qui ont esté crucifiez por le commandement du Roy de Jappon. Rouen: Thédore Reinsart, 1599. In: GÓMEZ-GÉRAUD, Maria Cristina. 2003. Le théâtre des premiers martyrs japonais: la leçon de théologie, op. cit, p. 177.

${ }^{90}$ JACQUELARD, Clotilde. Une catastrophe glorieuse: le martyre des premiers chrétiens du Japon, Nagasaki, 1597, op. cit, par. 16.

${ }^{91}$ Ibid.

${ }^{92}$ CARDIEL, José. Parte de la América Meridional en que trabaja el zelo de los religiosos de la Compañía de Jesús de la Provincia dicha del Paraguay. 1760. In: FURLONG, Guillermo. Cartografía jesuítica del Río de la Plata. n. 32. Buenos Aires: Jacobo Peuser, 1936.

${ }^{93}$ FERRAND DE ALMEIDA, André. Samuel Fritz and the Mapping of the Amazon. Imago Mundi, n. 55, p. 113-119, 2003. p. 117.

${ }_{94}$ PAGE, Carlos. Siete Ángeles. Jesuitas en las reducciones y colegios de la antigua Provincia del Paraguay. op. cit., p. 125.

${ }^{95}$ Ibid.

${ }^{96}$ Cf. RICOEUR, Paul. La Mémoire, l'Histoire, l’Oubli, op. cit., p. 275.
} 
El análisis de los martirologios producidos en el contexto de las guerras de religión evidenció que también en el terreno de los discursos se llevaron a cabo las disputas por la legitimidad entre católicos y protestantes, que éstas se conjugaron en tiempo pasado y en el espacio subterráneo en el que quedó una memoria enterrada. Los éxitos arqueológicos impulsaron las políticas culturales del martirio y la producción de tres tipos de mediaciones de memoria: conjuntos arqueológicos divinos en tanto prueba fehaciente del vínculo que unía a los católicos con los primeros mártires, ciclos del martirio en iglesias y conventos que permitían incorporar las historias de los primeros mártires a la práctica litúrgica y al ciclo formativo de los novicios, y que eran complementados a su vez con un tercer tipo de mediaciones de memoria: libros de pequeńo formato que apoyándose en las representaciones de los mártires y el martirio acompañaban a los novicios hacia las últimas fronteras en las que los herederos directos de los primeros mártires repetirían el ejemplo de sus predecesores manteniendo viva su memoria. Adversas, hostiles y lejanas, las últimas regiones descubiertas serían los escenarios propicios para que los herederos de los primeros mártires repitiesen el ejemplo de sus predecesores manteniendo viva su memoria.

\section{Referências biliográficas}

ACOSTA, José de. Historia natural y moral de las Indias. Alicante: Biblioteca Virtual Miguel de Cervantes, 1999 [1590].

ANDERSON, Benedict. Comunidades imaginadas. México: FCE, 2000.

BALANDIER, Georges. Le pouvoir sur scène. París: Fayard, 2006 [1980].

BARCELOS, Artur. Os jesuítas e a ocupação do espaço platino nos séculos XVII e XVIII. Revista Complutense de Historia de América, n. 26, p. 93-116, 2000.

BELTING, Hans. The End of the History of Art?. Chicago: The University of Chicago Press, 1987.

BERCHTOLD, Jacques; FRAGONARD, Marie-Madeleine (Ed.). La mémoire des guerres de Religion. La concurrence des genres historiques, XVIe-XVIIIe siècles. Actes du colloque international de Paris. (15-16 novembre 2002) Genève: Droz, 2007.

BEZERRA DE MENESES, Ulpiano. Fontes visuais, cultura visual, História visual. Balanço provisório, propostas cautelares. Revista Brasileira de História, v. 23, n. 45, p. 11-36. 2003.

CARDIEL, José. Parte de la América Meridional en que trabaja el zelo de los religiosos de la Compañía de Jesús de la Provincia dicha del Paraguay. 1760. In: FURLONG, Guillermo. Cartografía jesuitica del Río de la Plata. n. 32. Buenos Aires: Jacobo Peuser, 1936.

CASTELNAU-L'ESTOILE, Charlotte de. Compartir las reliquias. Indios Tupíes y jesuitas frente a los huesos de un misionero Chamán en el Brasil de inicios del siglo XVII. In: WIL- 
DE, Guillermo (Ed.). Saberes de la conversión. Jesuitas, indígenas e imperios coloniales en las fronteras de la cristiandad. Buenos Aires: SB, 2011.

CAVALIERI, Giovanni. Ecclesiae Militantis Triumphi. Roma, 1583.

CHALFEN, Richard. Photography. In: LEVINSON, David; EMBER, Melvin (Eds.). Encyclopedia of Cultural Anthropology. Nova York: Holt, 1996, n. 3, p. 926-31.

CHRISTIAN, William. Apariciones en Castilla y Cataluña (siglos XIV-XVI). Madri: Editorial Nerea, 1990.

. Local Religion in Sixteenth-Century Spain. Princeton: Princeton University Press, 1989.

CRESPIN, Jean. Actes de Martyrs, S/E, 1554.

DE LAS CASAS, Fray Bartolomé. Breve relación de la destrucción de las indias occidentales. México: Ontiveros, 1822 [1552].

DE MOURA SOBRAL, Luis. Pintura, santos y propaganda: la sacristía del antiguo colegio de los jesuitas de Salvador, Bahía. In: Territorio, Arte, Espacio y Sociedad, Actas III Congreso Internacional del Barroco Americano: Universidad Pablo de Olavide, Sevilla, 8 al 12 de octubre de 2001.

DEKONINCK, Ralph. Imaginar la ciencia: la cultura emblemática jesuita entre ars rethorica y scientia imaginum. In: CHINCHILLA, Perla; ROMANO, Antonella (Coord.). Escrituras de la modernidad. Los jesuitas entre cultura retórica y cultura científica. Ciudad de México: Universidad Iberoamericana, 2008.

EHRMANN, Jean. Massacre and Persecution Pictures in Sixteenth Century France. Journal of the Warburg and Courtauld Institutes, n. 8, p. 195-199, 1945.

FABRE, Pierre Antoine. Décréter l'image? La XXV'eme session du Concile de Trente dans le texte. París: Les Belles Lettres, 2013.

- Ignace de Loyola. Le lieu de l'image: Le problème de la composition de lieu dans les pratiques spirituelles et artistiques jésuites de la seconde moitié du XVIe siècle. París: Vrin/EHESS, 1992.

. Les Visions d'Ignace de Loyola dans la diffusion de l'art jésuite. $M L N$, v. 114, n. 4, p. 816-847, 1999.

. Reliquias Romanas en México, historia de una migración. In: WILDE, Guillermo (Ed.). Saberes de la conversión. Jesuitas, indigenas e imperios coloniales en las fronteras de la cristiandad. Buenos Aires: Sb, 2011. p. 205-224.

FERRAND DE ALMEIDA, André. Samuel Fritz and the Mapping of the Amazon. Imago Mundi, n. 55, p. 113-119, 2003.

FOLEY, Henry. Records of the English Province of the Society of Jesus. Londres: Burns ans Oates, 1880, 6:83. En: NOREEN, Kirstin. Ecclesiae militantis triumphi: Jesuit Iconogra- 
phy and the Counter-Reformation. The Sixteenth Century Journal, v. 29, n. 3, p. 689-715, 1998.

FOXE, John. The Unabridged Acts and Monuments Online. 1576 [1563]. Sheffield: HRI Online Publications, 2011. URL: <http//www.johnfoxe.org>. Consultado: 9-12-2013.

FREEDBERG, David. Prints and the status of images in Flanders. En: ZERNER, Henri (Ed.). Le Stampe e la diffusione delle Immagini e degli Stili (Atti del XXIV Congresso Internazionale di Storia dell'Arte, 1979, v. VIII, Bologna, 1983, p. 39-44.

. The hidden god: image and interdiction in the Netherlands in the sixteenth century. Art history, v. 5, n. 2, p. 133-153, 1982.

. The power of images. Studies in the History and Theory of Response. Chicago: University of Chicago Press, 1989.

. The Representation of Martyrdoms during the Early Counter-Reformation in Antwerp. Burlington Magazine, v. 876, n. 118, p. 128-138, 1976.

FROES, Louis. Histoire de la glorieuse mort de vingt six chrestiens qui ont esté crucifiez por le commandement du Roy de Jappon. Rouen: Thédore Reinsart, 1599. Apud: GÓMEZ-GÉRAUD, Maria Cristina. Le théâtre des premiers martyrs japonais: la leçon de théologie. In: LESTRINGANT, Frank; MOREAU, Pierre-François et al. Martyrs et Martyrologues. Revue de Sciences Humaines, n. 269, p. 175-187, 2003.

GEERTZ, Clifford. Negara. The Theater State in Nineteenth Century in Bali. Princeton: Princeton University Press, 1980.

GELL, Alfred. Art and agency. An Anthropological Theory. Oxford: Clarendon Press, 1998. GIUDICELLI, Christophe; RAGON, Pierre. Les martyrs ou la Vierge? Frères martyrs et images outragées dans le Mexique du Nord (XVIème-XVIIème siècles). Nuevo Mundo Mundos Nuevos. par. 2 y 14, 2005. URL: http://nuevomundo.revues.org/615. Consultado: 1011-2013.

GÓMEZ-GÉRAUD, Maria Cristina. Le théâtre des premiers martyrs japonais: la leçon de théologie. In: LESTRINGANT, Frank; MOREAU Pierre-François et al. Martyrs et Martyrologues. Revue de Sciences Humaines, n. 269, p. 175-187, 2003.

GRUZINSKI Serge. La Pensée métisse. París: Éditions Fayard, 1999.

. La guerra de las imágenes. De Cristóbal Colón a "Blade Runner" (1492-2019). México: FCE, 1994 [1990].

Herejes e infieles: imaginación etnográfica, experiencia histórica y prácticas comunicativas de la alteridad en la obra de De Bry. Revista Brasileira de História das Religióes, v. 7, n. 19, p. 91-106, 2014.

JACQUELARD, Clotilde. Une catastrophe glorieuse: le martyre des premiers chrétiens du Japon, Nagasaki, 1597. e-Spania, n. 12. 2011. URL: <http://e-spania.revues.org/20808>. Consultado: 21-10-2013. 
JOUANNA, Arlette et al. Historie et dictionnaire des guerres de religion. París: Laffont, 1998. LABROT, Gérard. L'image de Rome: une arme pour la Contre-Réforme, 1534-1677. París: Champ Vallon, 1987.

LESTRINGANT, Frank; MOREAU, Pierre-François. Ouverture. Revue de Sciences Humaines, n. 269, p. 7-13, 2003.

LIFSCHITZ, Javier Alejandro; ARENAS GRISALES Sandra Patricia. Memoria política y artefactos culturales. Estudios Politicos, n. 40, p. 98-119, 2012.

LÓPEZ, Sebastián. Contrarreforma y Barroco. In: FAJARDO DE RUEDA, Marta. El espiritu barroco en el arte colonial. Bogotá: BLAA, 1981. p. 61-91. URL: <http://www.banrepcultural.org/blaavirtual/todaslasartes/ext/ext13.htm\#4a>. Consultado: 18-11-2013.

MAXWELL Kenneth. The Spark: Pombal, the Amazon and the Jesuits. Portuguese Studies, n. 17, p. 168-183, 2001.

MONSSEN, Leif Holm. Rex Gloriose Martyrum: A Contribution to Jesuit Iconography. The Art Bulletin, v. 63, n. 1, p. 130-137, 1981.

MONTORO CASTILLO, Mónica. Los oratorianos de San Felipe Neri y los inicios de la arqueología cristiana. CuPAUAM, n. 34, p. 147-154, 2008.

MUKERJI, Chandra. Printing, cartography and conceptions of place in Renaissance Europe Media. Culture \& Society, v. 28, n. 5, p. 651-669, 2006.

NORA, Pierre. Les lieux de mémoire. Gallimard: París, 1984.

NOREEN, Kirstin. Ecclesiae militantis triumphi: Jesuit Iconography and the CounterReformation. The Sixteenth Century Journal, v. 29, n. 3, p. 689-715, 1998.

ORDIZ VÁZQUEZ, Francisco Javier. El 'triunfo de los santos' y el teatro jesuita del siglo XVI en México, Anales de literatura hispanoamericana, n. 18, p. 19-28, 1989.

OSBORNE, John. The Roman Catacombs in the Middle Ages. Papers of the British School at Rome, n. 53, p. 278-328, 1985.

OSSWALD, Cristina. A iconografia do martírio na Companhia de Jesus entre os sécs. XVI e XVIII. Revista Portuguesa de Filosofia, n. 65, p. 1301-1313, 2009.

PAGE, Carlos. Siete Ángeles. Jesuitas en las reducciones y colegios de la antigua Provincia del Paraguay. Buenos Aires: Paradigma Inicial, 2011.

PARUTA, Paulo. The history of Venice; likewise the wars of Cyprus, wherein the famous sieges of Nicossia, and Famagosta, and Battel of Lepanto are contained. SF. p. 126 URL: $<$ http://quod.lib.umich.edu/e/eebo/A56527.0001.001/1:8?rgn=div1;view=fulltext>. Consultado: 24-03-2015.

PERRISSIN, Jean; TORTOREL, Jacques. Premier volume contenant quarante tableaux ou Histoires diverses qui sont mémorables touchant les Guerres Massacres et Troubles advenus en France en ces dernières années. Le tout recueilli selon les témoignages de ceux qui y ont été en personne, et qui les ont veus, lesquels sont pourtrais à la vérité. S/E, S/F. 
RALSTON CAWLEY, Robert. George Gascoigne and the Siege of Famagusta quick view. Modern Language Notes, v. 43, n. 5, p. 296-300, 1928.

RANCIÈRE, Jacques. Figuras de la Historia. Buenos Aires: Eterna cadencia, 2013 [2012].

RICHARDSON, Carol. Durante Alberti, the Martyrs' Picture and the Venerable English College, Rome, Papers of the British School at Rome, n. 73, p. 223-263, 2005.

RICOEUR, Paul. La Mémoire, l'Histoire, l'Oubli. París: Seuil, 2003.

RODRÍGUEZ G. DE CEBALLOS, Alfonso. El mártir, héroe cristiano. Los nuevos mártires y la representación del martirio en Roma y en España en los siglos XVI y XVII. Quintana: Revista de estudios do Departamento de Historia da Arte, n. 1, p. 84-99, 2002.

SALAMANCA VILLAMIZAR, Carlos S. "Religión, política y espectáculo: narrativas del martirio en la primera modernidad", 2015, mimeo.

SCHNITZLER, Henry. The Jesuit Contribution to the Theatre. Educational Theatre Journal, v. 4, n. 4, p. 283-292, 1952.

TILL, Karen. Artistic and activist memory-work: Approaching place-based practice. $M e-$ mory Studies, v. 1, n. 1, p. 99-113, 2008.

TURNER, Victor. La selva de los símbolos. Buenos Aires: Siglo XXI, 1999.

VERSTEGAN, Richard. Théâtre des cruautés des hérétiques de notre temps. Paris: Editions Chandeigne, 1995 [1557]. URL: <http://gallica.bnf.fr/ark:/12148/bpt6k1040506g>. Consultado: 12-3-2014.

WASSERMAN, Renata. The Theater of José de Anchieta and the Definition of Brazilian Literature. Luso-Brazilian Review, v. 1, n. 36, p. 71-85, 1999.

WHITE, Hayden. El pasado práctico. In: TOZZI, Verónica; LAVAGNINO, Nicolás. Hayden White, la escritura del pasado y el futuro de la historiografia. Buenos Aires: Eduntref, 2012. WILDE, Guillermo. The Political Dimension of Space-Time Categories in the Jesuit Missions of Paraguay (17th and 18th Centuries). In: MARCOCCI, Giuseppe; DE BOER, Wietse; MALDAVSKY, Aliocha; PAVAN, Ilaria (Eds.). Space and Conversion in Global Perspective. Leiden: Brill, 2014. 